\title{
The need for protecting, promoting, and managing a Quaternary geoheritage site: Bahluiet Valley at Costești village (Moldavian Plateau, North-Eastern Romania
}

Mihai Niculita ( $\nabla$ mihai.niculita@uaic.ro)

Alexandru Ioan Cuza University of lasi https://orcid.org/0000-0003-0351-5512

\section{Research Article}

Keywords: geoheritage site, geomorphosite, archaeological site, landslides, fluvial terraces, Moldavian Plateau

Posted Date: February 15th, 2021

DOI: https://doi.org/10.21203/rs.3.rs-162251/v1

License: (9) This work is licensed under a Creative Commons Attribution 4.0 International License. Read Full License

Version of Record: A version of this preprint was published at Geoheritage on February 1st, 2022. See the published version at https://doi.org/10.1007/s12371-022-00645-4. 
The need for protecting, promoting, and managing a Quaternary geoheritage site: Bahluieț Valley at Costești village (Moldavian Plateau, North-Eastern Romania) geoheritage site. Previously this area was investigated due to the presence of the Costești-Cier archaeological site, 20A, 705505, Iași, Romania

mihai.niculita@uaic.ro,+40742824349,+40232 201474 which is currently integrated into the National Archaeological Repertoire. In this archaeological site, different levels of populations have been studied (Eneolithic Cucuteni A, Cucuteni AB, and Horodiștea-Erbiceni Culture populations) as well as an earth wall from La Tene (8th-10th/11th century BC), and a 15th-17th century AD necropolis. In the area of the present-day Costești village, Bahluieț River leaves the Suceava Plateau area (with altitudes of 350-550 m a.s.l.) and enters the Jijia Hills (with altitudes of 50 to $200 \mathrm{~m}$ a.s.l.), flowing between Ulmiș Hill (306 m a.s.l., at north) and Ruginii Hill (326 m a.s.l., at the south). The valley, which is incised more than $100 \mathrm{~m}$ below the plateau level, suddenly becomes broader because of massive Late Pleistocene landslides that covered the former Bahluieț river floodplain and are now fossilized by fluvial deposits. During the Holocene, the river incision detached paleochannels and fluvial terraces while the landslides reactivated through retrogressive mechanisms, creating a complex landslide. A cut-off meander island hosts the Costești-Cier archaeological site, being currently actively eroded by the river. In the riverbank of this island, a multi-layered stratigraphy can be seen, consisting of landslide and fluvial deposits, paleosoils, and archaeological remains. The layered deposits, the complex landslide, and the fluvial processes have the potential to become one of the most representative Quaternary sites of the Moldavian Plateau and Romania. By using geomorphosite assessment, geomorphological mapping optically stimulated luminescence dating, and geoconservation ideas, I show (i) the importance of the geosite due to the presence of the oldest dated fossil landslide from Romania and the landslide-fluvial-archaeological relations, (ii) the needs for protection at local, regional and national level considering the active processes that affect the site, and propose (iii) management and (iv) promotion of the geoheritage site using a geoconservation strategy. 


\section{Introduction}

Fluvial erosion and mass wasting are geomorphologic processes control landform evolution (Korup and Schlunegger 2007; Larsen and Montgomery 2012) and create specific landforms: valleys, channels, and landslides. These processes are geomorphological hazards with adverse effects on human society (Monteleone and Sabatino 2014; Davies 2015).

The Moldavian Plateau is a lowland hilly area representative for Romania (Fig. 1), where landslides are a permanent phenomenon, coexisting and having feedbacks with the river incision (Mărgărint and Niculiță 2017). In this area, landsliding initiated from the Holocene (Niculiţă et al. 2016a) or even the Pleistocene (Niculiţă et al. 2016b; Niculiță 2020) periods, and reactivated intensively during the Holocene and in recent times (Niculiță et al. 2016a; Niculiță et al., 2016b: Niculiță 2020). The landslided areas are a space where many villages or cities developed during the time, so the destructive potential of landslides could have negative influences on human society (Văculişteanu et al., 2019). At the same time, in ancient periods, the topography shaped by the landslide processes, represented by hill plateau bordered by steep escarpments tens of meters high, provided the ancient populations naturally defensive places to build their hillforts and fortified settlements (Fig. 1 - locations of other fortified sites from the Moldavian Plateau are shown). The archaeological topography was used to assess the relative chronology of landslides from the Moldavian Plateau during the Holocene (Niculiță et al. 2016a, 2019). These locations are important heritage sites for Romanian prehistory, where landslides also developed after the population disappearance representing a significant risk factor for these archaeological sites (Niculiță and Mărgărint 2018). River and gully incision, which triggers but also follows landsliding, is destroying physically entire or parts of geoheritage and archaeological sites. The geomorphological, paleogeographical, and archaeological heritage was used to argue for the geoheritage status (Niculiță and Mărgărint, 2018) of such ten sites described first by Niculiță et al. (2016a).

From the ten sites, two showed the potential to represent great importance for the Moldavian Plateau geoheritage by having the biggest score in a geomorphosite evaluation (Niculiță and Mărgărint 2018): Băiceni Hillslope and Bahluieț Valley at Costești village. While the Băiceni Hillslope obtained the highest score, the Bahluieț Valley at Costești village appeared attractive because the landsliding and the archaeological topography are also related to fluvial terraces and fluvial processes, which generated the exposure of the layered deposits that formed through the interaction of the mentioned processes. It was assessed that these layered deposits have the potential to show the Pleniglacial to Holocene evolution of the contact area between the Suceava Plateau and Jijia Hills and are one of the most representative Quaternary sites of the Moldavian Plateau (Niculiță et al. 2017; Niculiță and Mărgărint 2018; Niculiță 2020).

Considering these aspects is of a real scientific and practical interest to study the complex interactions between archaeological heritage sites, rivers, and landslides and the implications for the management of this important site. This study describes the geomorphological and archaeological context of the Bahluieț Valley at the Costeşti village geoheritage site (Fig. 2) and argues for protecting, promoting, and managing through geoconservation. 


\section{Study area}

\subsection{Geological and geomorphological setting of the Bahluieț Valley at Costești}

Costești village is located at the transition of the Bahluieț river from the Siret Plateau (Tufescu 1935, 1937a, b), a subdivision of the Suceava Plateau (east of Siret River) to Jijia Hills (Fig. 2). In this area, the Bahluieț river is flowing between Ulmiş hill (306 m a.s.1.) at north and Crucii hill (235 m a.s.l.) with a north-west to a south-east direction (Fig. 3). The river incised in the monoclinal strata with a north-west to a south-east dip direction of the Carpathian foreland basin (de Leeuw et al. 2020), exposing the Miocene strata as bands along the hillslopes. The Serravallian to Tortonian (in the Dacian Basin corresponding to Volhynian to Bessarabian) deposits are mud-rich siliciclastic offshore deposits in front of an axial fluvial-deltaic system, covered by late Bessarabian shoreline prograding shell-rich deposits (de Leeuw et al. 2020). The foreland basin was overfilled at 5.8 Ma, but the exhumation in the north-western part is older (even $12 \mathrm{Ma}$ ), showing post-orogenetic uplift and a gentle south-east tilt, several hundred meters of sediment being eroded (de Leeuw et al. 2020). The Pleistocene to Holocene evolution of the study area is not well dated, but the general framework was established by Niculiță (2020) with radiocarbon dating: the Late Pleistocene (Pleniglacial - Railsback et al. 2015 and Cohen and Gibbard 2019, before Marine Isotope Stage 3, $45 \mathrm{ka}$ respectively) age of the Costești fossil landslide, the Middle to Late Pleniglacial (MIS2-MIS3, 46-20 ka respectively) age of the 7-15 m Bahluieț River terrace at Costești, the Late Pleniglacial (20 ka) age of the 20-25 m Bahluieț River terrace at Mădârjești, both detached through Lateglacial valley incision and widening, and the Lower to Middle Holocene (8-4 ka) filling of the valley with floodplain formation which is stable since 2-3 ka. In the last $2 \mathrm{ka}$, the present-day channels incised and the floodplain aggraded through flood mud deposition (Niculiţă 2020). The landslide activity model is consistent with this framework, the magnitude of the landslide events decreasing toward the present day and the activation moving from the base slope to upslope through a retrogressive mechanism and generating compound and complex landslides covering entire hillslopes (Niculiță et al., 2016a, 2019; Niculiță 2020).

The geology of the study area was studied by Cobălcescu (1883), Tufescu (1935), Macarovici and Turculeț (1956), Ștefan (1989), and Ionesi et al. (2005). The correlation of the Eastern Parathethys regional stratigraphy with the International Chronostratigraphic Chart (Cohen et al. 2013) was established based on the information from Pevzner and Vangengeim (1993), Jones and Simmons (1997), and Rögl (1998) and is shown in Figure 4. The most detailed lithostratigraphic column was created by Ștefan (1989) and began with Late Volhynian rocks (Fig. 4): Oneaga Clays Formation and the overlapping Lespezi-Tudora Sands (Fig. 5b) and Sandstones Formation. The Oneaga Clays Formation (220 m thickness) comprises compacted and stratified mudstones at the basal part, which has sand lentils or sand layers at the upper part, and appears tilted in some sectors (Ștefan, 1989 - as is also the case of Fig. 5a). In the study area, these rocks outcrop only in the Bahluieț channel downstream the landslide area. The Lespezi-Tudora Sands and Sandstones Formation is $35 \mathrm{~m}$ thick and is composed of intercalations of grey sand levels and quarzitic sandstones. The sands were also found downstream of the landslide area, in the floodplain, and are altered (Fig. 5b). The overlapping Early Bessarabian rocks suite starts with the Băiceni Clays and Sands Formation (40-100 m thickness), which is composed of basal mudstones and siltstones overlapped by quarzitic sands. In the study area for the Băiceni Clays, there is a bluish-grey mudstone facies with thin sand intercalations found in a quarry on the left landslide hillslope (Fig. 5c). The Băiceni Sands Formation was found in a quarry (opened for the construction of the earth dams 
from Fig. 2), downstream the study area as a siltstone with sand intercalations (Fig. 5d). The Hărmănești Oolitic Limestone (maximum 4-5 m thickness, composed of slates of oomicrite), covers the Băiceni Sands and Clays Formation and was only found as a fragment in the Băiceni Sands quarry (the inset from Fig. 5d). Over the oolitic limestone, there is a layer of quarzitic sands known as Bahlui-Sirețel Sands Formation, with 10-15 m thickness and is well outcropping in a gully downstream of the study area and upslope of the Băiceni Sands quarry (Fig. 5e). The second oolitic limestone level, named Hârlău Oolitic Limestone Formation, also has 4-5 m thickness, with oolitic limestones. microconglomerates and sand layers (Fig. 5f). The Sticlăria-Sângeap Sands Formation with 35-40 m thickness composed of intercalations of sands and siltstones (Fig. $5 \mathrm{~g}$ ) is overlapped by the Crivești Oolitic Sandstone (4-5 m thickness) composed of quartz-arenites with oolitic limestone and sand layers (Fig. 5h), both identified in the study area. Humosu Sands has $100 \mathrm{~m}$ thickness with sands and layers of mudstones, but is highly eroded in the study area, appearing as a thin layer on the plateaus of the hills. Ionesi et al. (2005) consider the whole Bessarabian column as a single formation called Dealu Mare. The geological formations were identified in the field (Fig. 5), mainly upstream and downstream of the studied area (because in the study area are covered by landslide deposits), the Crivești Oolitic Limestone Formation outcropping continuously in the Costești landslide scarps (Fig. 5g).

The widening of the valley before the river reach the Jijia Hills lower area is due to multiples massive landslides (Niculiță et al., 2016a,b; Niculiță and Mărgărint 2018; Niculiță 2020), which deposited material in the floodplain. The landslides were favored by the geological framework and by the Bahluieț River incision (more than $125 \mathrm{~m}$ altitude amplitude). The age of the first generation of landslides (fossil landslides) was inferred to be at least Lateglacial from the stratigraphic relationship between the archaeological deposits, floodplain deposits, and the relict landslide body (Niculiță et al., 2016a,b; Niculiță and Mărgărint 2018). Later, using radiocarbon data from the floodplain deposit (Niculiță 2020), the Late Pleistocene (Pleniglacial) age was confirmed. The fossil landslide bodies (due to the discontinuous outcropping, I cannot prove a single event) of thickness that we estimate to a maximum of $25 \mathrm{~m}$ (based on applying the sloping local base level approach -Jaboyedoff et al., 2004, 2013 constrained by the ERT data from Niculiţă et al., 2017) covered the former Bahluieț floodplain and were sealed with floodplain sediments of thickness between 2 to $7 \mathrm{~m}$ (based on the field investigation of Bahluieț river bank). In a later phase of fluvial evolution, the Bahluieţ river incised again in its own floodplain and in the landslide deposits, as an in-grown meandering valley (Davis 1906, 1913; Rick, 1914; Dury 1964, 1965), creating cut-off fossil meanders (meander cores or spurs) and detaching several terrace levels (5 to $15 \mathrm{~m}$ relative altitude). The meanders separated two islands after their cut-off, one of the islands being used by the ancient population for a fortified settlement (Boghean et al., 2014b).

137 Nowadays, the banks of the in-gown meander valley are continuously eroding due to the lateral migration of the active channel, especially in the case of the geoarcheosite island (Fig. 6). Further geomorphologic investigations and geophysical investigations are needed in order to fully understand the topographic setting of the Cucutenian site on the island and the adjacent floodplain.

After the initial Upper Pleistocene failures, triggered by the river incision, the landslides evolved in a retrogressive manner (Fig. 4), on both sides of the valley slopes, the landslide deposits from the floodplain and valley sides being multi-layered, as it also happens in other areas in Europe (Margielewski 2006; Alexandrowicz and Margielewski 2010; Pánek et al. 2014). The initial landslides that generated the now the fossil landslide deposits were 
rotational rock slides with long runout. Coring and further geophysical investigations are needed to establish the timing and the geometry of these deposits since the sources are both hillslopes, and a previous floodplain deposit might be covered by them. Nonetheless, the presence of the fossil landslide tilted deposits was validated in the field across the Bahluieț river banks (Fig. 6 and 7). The fluvial sealing deposits were covered by retrogressive reactivations (Fig. 7) that have rotational and translational mechanisms and were delineated using morphologic approaches on highresolution LiDAR DEMs (Niculiță et al., 2016a). and proposed as a geoheritage site (Niculiță and Mărgărint 2018) due to its geomorphologic, palaeogeographic, and archeological values. The area is known in the scientific literature and was studied in relation to the presence of the Costești-Cier archaeological site (Boghian 2009; Boghian et al. 2014a), recognized in the National Archaeological Repertoire (http://ran.cimec.ro/sel.asp?descript=costesti-costesti-iasi-situl-arheologic-de-la-costesti-cier-cod-sit-ran95541.01).

The archaeological site is located on the fluvial terrace and on a meander island of the Bahluieț river, in the Costești Commune, Iași County (Fig. 1, 2, 4, 6, 7, 8 and 9). The fluvial terrace site (Fig. 4 and 10) was heavily disturbed by the construction of the local road, of the local school, and of a soccer field after 2000 . The meander island started eroding in the '30 (Boghian et al. 2013), on the topographic army plans (http://www.geospatial.org/download/planurile-directoare-de-tragere?lang=en) and on the Ciurea (1938) schema the island having $\sim 2500 \mathrm{~m}^{2}$ (a hexagonal shape, and general measures of $68 \mathrm{~m} \mathrm{~N}-\mathrm{S}$ in length and $45 \mathrm{~m} \mathrm{~W}$-E in width) and an elevation amplitude of $25 \mathrm{~m}$ toward the surrounding floodplain. In the riverbank, the presence of the archaeological remains was remarked by the locals (Ciurea 1938). For the 1939 situation, Matasă (1940) mentions the presence of gullies on the hillslopes of the island (probably on the western bank).

The site was discovered by a primary school teacher (Vasile Diaconescu) before the World Second War and was investigated by several archaeologists in 1937 (Ciurea 1938), 1939 (Matasă 1940), 1940 (Mateescu 1940 ), 1943 (Vulpe 1944), and 1985-1991 (Boghian et al. 2014b). Currently, the area is in salvage investigation status, through seven successive archaeological campaigns between 2012 and 2019 (Boghian et al., 2013, 2014a, 2015, 2016, 2017) the entire upper part of the island being investigated in order to rescue the site, that is continuously affected by riverbank erosion (Fig. 10).

The archaeological investigations showed that the site has different levels of populations (Table 1), being a pluristratified site, with archaeological deposits up to 2 meters (Fig. 8). The oldest archaeological level is Cucuteni A followed by Cucuteni AB. Over the Cucuteni layers, as intrusions, there are: (i) a Horodiștea-Erbiceni Culture level with a necropolis, (ii) a medieval hut (8th-10th/11th century AD), and (iii) a $16^{\text {th }}$ to 17 th century AD necropolis with 35 burial tombs (Fig. 8). A Cucutenian defense earth ditch was also found on the southern slope of the mound.

From an archaeological point of view, the site is important mainly for the archaeological findings (Fig. 9): (i) anthropomorphic and zoomorphic representations (Enea et al., 2016), (ii) painted ceramics, with kernos type of religious vase (Boghian, 2012), (iii) chipped and polished stone artifacts (Boghian et al., 2014c), (iv) artifacts made 
of clay and other materials (Boghian et al., 2014c; 2015), (v) artifacts made of bone antler and boar tusk (Boghian et al., 2014c).

\section{Materials and methods}

\subsection{Geomorphological mapping}

Geomorphological mapping performed in the field and on high-resolution LiDAR DEM was used in order to establish a proper management plan. Three field surveys targeted geology recognition, the channel and terraces, and the landslides and gullies. The geomorphological mapping on the high-resolution data was made through automatic geomorphometric extraction in SAGA GIS (Conrad et al. 2015) and manual digitization in Quantum GIS (QGIS.org 2021). 2012 acquired LiDAR point clouds (4-6 points per $1 \mathrm{~m}^{2}$ ) were manually refined in order to obtain ground data, and through multilevel B spline interpolation, two DEMs were obtained (Niculiță et al. 2020b can be seen for details on the interpolation), one at $0.25 \mathrm{~m}$ spatial resolution for detailed manual mapping, and one at $5 \mathrm{~m}$ spatial resolution for automatic geomorphometric mapping.

The conceptual mapping system is based on the landforms that are considered important from the geoheritage point of view: landslides (delineated after Niculiță et al. 2016a and Niculiţă 2020, guidelines using the Cruden and Varnes 1996 landslide elements), river channel, riverbanks, meander islands, fluvial terraces, and gullies. Generic catena-type units (Niculiță 2011) and the fuzzy curvature-based classification (Schmidt and Hewitt, 2004) implemented in SAGA GIS (Conrad et al., 2015) were used to frame the detailed mapping.

Based on the geomorphological characteristic of the study area, the following landforms types were mapped: (i) floodplains, consisting of the channel extracted by thresholding catchment area and the plain, channel, pit, and saddle classes of Schmidt and Hewitt (2004) located at low altitudes, (ii) hillslopes, consisting of the foot, back and shoulder types of slope, hollows and spurs of Schmidt and Hewitt (2004), (iii) plateaux consisting of plain, channel and saddle classes of Schmidt and Hewitt (2004) and located at high altitudes, (iv) ridges, consisting of ridge and peak classes of Schmidt and Hewitt (2004) and located at high altitudes, and (v) terraces, consisting of the saddle, channel, pit and peak classes of Schmidt and Hewitt (2004) and located on the hillslopes, around the Bahluieţ channel.

\subsection{Absolute dating of the terrace deposits}

Because in the area of the geomorphoarcheosite, the terrace deposits do not contain datable organic matter, the optically stimulated luminescence dating method was chosen to establish the chronology of the geomorphological evolution. The samples were taken in custom-made sharpened steel tubes which were inserted in the sediment using a pounding cap. An aluminum foil plug was inserted at the sharpened end in order to fix the sample, avoiding sample mixing, and an aluminum end cap was used to seal the sample. Soil density drive tubes were used to sample material for gravimetric water estimation. The samples were dried in an oven at $110^{\circ} \mathrm{C}$ for 24 hours, and the percentage of water from the sample was derived through weighting before and after drying. The sample for the environmental dose rate was taken from a $20 \mathrm{~cm}$ range around the sample location. 
Two samples were collected from the terrace deposit under the archaeological site, which outcrops in the river bank (Fig. 6c). The first sample was taken from a depth of $1 \mathrm{~m}$ under the paleosoil and $3 \mathrm{~m}$ from the surface. The second sample was taken from $1 \mathrm{~m}$ below the first. Approx. $15 \mathrm{~cm}$ of exposed sediment were removed prior to the sampling.

The optically stimulated luminescence dating was performed by György Sipos from the OSL laboratory of the Szeged University. The laboratory is equipped with a RISO TL/OSL DA-15 luminescence reader fitted with a calibrated $90 \mathrm{Sr} / 90 \mathrm{Y}$ source. Stimulation of the grains was carried out using a blue $(470 \mathrm{~nm})$ and IR $(870 \mathrm{~nm})$ light emitting diodes (LED), and the detection was done through a U-340 filter. Different types of the Single Aliquot Regeneration (SAR) protocol was used (Murray and Wintle 2000; Murray and Wintle 2003; Wintle and Murray 2006; Thiel et al. 2011; Buylaert et al. 2012) for measurements. Prior to the measurement of the equivalent dose (De) tests were carried out to determine optimal temperature parameters and the reproducibility of the SAR procedure (combined preheat and dose recovery test). The equivalent dose was determined on several aliquots in case of each sample. Only those aliquots were considered for De calculation which passed the following rejection criteria (recycling ratio: $1.00 \pm 0.10$; maximum dose error: $10 \%$; maximum recuperation: 5\%, maximum IR/OSL depletion ratio: 5\%)

Sample De was determined on the basis of each accepted aliquot De, using different statistical techniques (Galbraight et al. 1999). A decision was made on the basis of overdispersion, skewness, and kurtosis values. Environmental dose rate $\mathrm{D}^{*}$ was determined on the samples using a high-resolution, extended range gamma spectrometer (Canberra XtRa Coaxial HpGe detector). Dry dose rates were calculated using the conversion factors of Liritzis et al. (2013), while wet dose rates were assessed on the basis of in situ water contents. The dose rate provided by cosmic radiation was determined on the basis of the geographical position and depth of the samples below ground level, using the equation of Prescott and Hutton (1994). applied by Niculiță and Mărgărint 2018 was used to recompute the values.

\subsection{Geomorphosite evaluation}

Considering that the present study improved the knowledge about the geomorphosite, the methodology

\subsection{Geoheritage conservation}

For the implementation of geoconservation proposal a review of the literature was performed in order to identify both theoretical (Ellis et al. 1996; Erikstadt 1999; Gray 2004, 2019; Dunlop et al 2018; Gordon et al. 2018a,b; Gordon 2019) and practical (Progeo 2011; Crofts et al. 2020) aspects but also study cases (Lima et al. 2013; Gordon 2016).

\section{Results}

\subsection{Geomorphological evolution of the geoheritage site}

Sine the evaluation from Niculiță and Mărgărint (2018) of the Bahluieț Valley at Costești geoheritage site, when the Late Pleistocene age was inferred for the fossil landslide, this age was confirmed (Niculiță 2020). In the 
LAHAMP project (Niculiță 2020), radiocarbon dating for several landslide sites in Moldavian Plateau was performed. While the majority of the landslide sites were dated to Holocene, the organic matter from the terrace deposits that cover the Costești fossil landslide returned 45 920-43 985 cal BP (Beta Analytics ID 518575). This result implies that fossil landslide was triggered before MIS3. The fieldwork along the Bahluieț channel network identified fossil landslide deposits under the terrace deposits in another four places (Fig. 7) beside the ones from the geoarchaeosite. Due to the lack of other datable organic material, in the section of the geoarchaeosite, two samples from the terrace deposits were dated with OSL. The results (Table 2) show the late Pleniglacial age of the 3.5-4 m thick floodplain deposits that sit over the landslide deposits. In this context, it is clear that the fossil landslide deposits correspond to different events and that the floodplain deposition of the terrace was also variable in thickness and rate.

At the current geomorphologic research stage, the Late Pleistocene age of the fossil landslide is it well constrained, without the possibility to say the precise timing of the triggering, but only upper bounds. These bounds imply that multiple events generated the landslide deposit. Future research, through geophysical investigation and deep coring, might be able to show the age of the landslide events directly from landslide deposit dating or by constraining using the dating of the possible floodplain deposits fossilized by the landslides. The geomorphological mapping shows the continuity of the retrogressive landslide reactivations, that generated a complex landslide, during the evolution of the hillslopes. This landslide occupies the Bahluieț Valley, with fossil material from both hillslopes, fluvial cover, and Lateglacial and Holocene reactivations. The topography of the terrace deposits is not smooth, showing the presence of paleochannels and meander islands, the current incised channel being recent.

\subsection{Geomorphosite evaluation}

The new data regarding the geomorphological evolution of the study area improves the geomorphosite assessment of Niculiță and Mărgărint (2018), making the present discussed geosite the most important in Moldavian Plateau (Table 2) and very close to other important geosites from Romania (through comparison with Viştea Glacial Valley - Comănescu and Nedelea 2017). In the case of scientific value (SV from Table 2), considering the representation (3.4 from Table 2) the erosion and deposition features of both old and present actual processes are clearly defined. Regarding the rareness (3.5 from Table 2), the fluvial incised fossil landslide is the only occurrence in Romania. The diversity of elements ( 3.9 from Table 2 ) is increased, with three other elements being present besides the two evaluated in 2018 (fossil landslides, relict landslides, old landslides, meander islands, terraces).

In relation to additional value (ADIT from Table 2) the protected site value has risen since taking into account the full extension of the landslides. The geosite is under $5 \mathrm{~km}$ from Sârca-Podu Iloaiei reservoirs special area of conservation (SAC) for avifauna.

The esthetic value (AEST from Table 2) changes considering the landslide complex, the observation conditions (5.1 from Table 2) increasing due to multiple belvedere points and no view restrictions both from the geomorphoarcheosite and from the hillslopes.

Regarding the economic value (ECON from Table 2), the accessibility ( 7.1 from Table 2 ) is raised due to the access in the geoheritage site directly from the DN8A road and the access to the geomorphoarcheosite on paved roads. 

since the geoheritage site is very large, and it will suffer damage only from construction or mining activities, which is also improbable.

\subsection{Proposals for the geoconservation strategy}

In the current state of scientific knowledge, it is argued for the geoconservation of the geoheritage site. In this sense, a geoconservation strategy based on scientific research, community involvement, and educational outreach are proposed. The strategy is as follows: (i) the geoheritage site needs to be recognized under a legal framework in order to make authorities aware of the protection needs, (ii) conservation agencies and groups need to be outreached in order to establish specific conservation approach plans, (iii) scientific study needs to be extended and used in auditing of the site, (iv) conservation proposals needs to be formalized in a plan (Fig. 10), (v) after the plan is materialized, the touristic management need to become functional and (vi) future opportunities need to be assessed.

\section{Discussions}

\subsection{Rationale for protecting and managing geoheritage sites}

Protected areas are key elements of the conservation of ecosystems, although these tools were contested (Woodley 1997). While this role cannot always be attributed to geoheritage sites, their protection and conservation are required, at least from a scientific point of view. Geoheritage sites are natural sites that have an outstanding value from a geological and geomorphological point of view. Regarding the global approaches of nature conservation, geoheritage sites have various spatial scales and can be inside or harbor unique ecosystems that need to be protected, in which case the conservation need and their intrinsic value is added to the biological part. In other situations, while geosites harbor ecosystems, these may not be necessarily unique, but the association creates unique landscapes, very often impacted by humans, which also might require conservation, both from a biological, natural, and cultural point of view (Phillips 1997). According to IUCN classification of protected areas, geoheritage sites can be assigned to 312 World heritage sites or Geoparks (Dingwall et al. 2005). Usually national designation is made based on the 313 geological/geomorphological value, but very often are included in wider protected areas (Dingwall et al. 2005). The 314 equivalence between IUCN categories and Romanian protected areas categories is shown in Fig. 11.

The protection of geoheritages site is important for maintaining geodiversity and biodiversity, which is a generally good thing but is crucial for some poor areas (Brockington and Wilkie 2015). The benefits for society are 317 related to funding and the activities that can be attracted (Mansourian et al. 2008).

318 Considering the geoarchaeological and geomorphological context of the Costeşti Cier archaeological site and its surroundings Niculiță and Mărgărint (2018) argued that the area could be considered a geoarchaeosites and a geosite. Besides this formal status and the protection of the archaeological site, clear measures should be taken in order to assign national protection status. We propose first the inclusion as a county-level protected area and later as a natural monument (Fig. 11). Further on, threats due to the continuous erosion of the Bahluieț river must be addressed in order to protect the site and assure its management. This is an immediate need (McDonald 1990) since the erosion is active, and year by year, the riverbank is receding (Fig. 12). In order to respond to this threat, two possible 
approaches are in place: salvage excavations of the archaeological site (which are in progress) or measures of bank stabilization in order to protect the site in place.

\subsection{State or community-based conservation of the Costești geoheritage site?}

State-managed conservation can benefit from better funding and better management and regulation, but at the same time, the failure to provide both funding and good management might require local community involvement. While this would be beneficial, especially if geoheritage tourism can provide profit for the local community in rural areas (Bandyopadhyay et al. 2009; Lapeyre 2010), there are frequent cases when this fails (van der Straaten 1997; Emerton 2001), especial if the local communities are not well prepared, both technically and theoretically (Blangy 1997).

Assigning a cultural value to a geoheritage site could benefit its protection as it happens with wildlife (Infield 2011), both in a state and local community-managed conservation. Especially if the value added by geoheritage sites is related to geoscience and environmental education, this could improve the support of the local communities (Biderman and Bosak 1997). Also, when the geoheritage areas are small, overlain by human communities, and in ownerships of local landlords or communities, local stewardship initiatives could prove to work (Brown and Mitchell 1997) or not (Varangu 1997).

In the case of Costești geoheritage site, given the recent scientific interest, currently, there is no protection but for the archaeological site. According to the Romanian law (Ordnance 43 from 2000, 258 Law from 2006) archaeological sites are protected by the local and the county administration, and the protected surface is defined either as a surface where the remains were found, as a buffer around the spot or as the entire surface where the geomorphological processes expose the archaeological deposit. Currently, there is no unified geodatabase showing the extent of these protected areas as is the case for natural protected areas, but only an inventory, which has a spatial component (point placed on the geographical position of the site in the best case) and includes an estimate of the site area (given in ha). For Costești Cier archaeological site, which is included in the Costești geoheritage site, the archaeological area is in continuous shrinkage (Fig. 12). The archaeological investigations are mainly for salvage since the fluvial terrace site was destroyed by anthropic interventions, and the relict of meander island is eroding (Gania et al. 2012).

At the current state of the site's legal protection status, funds can be attracted by the local authorities or by the Prut-Bârlad Water Administration in order to protect the river bank. Funding for establishing a signaling network, promotion, and further studies or specific facilities for geosite management, can be attracted either by the local action groups (http://galiasisudvest.ro/) or by the county administration. The funding required for protection, management and conservation could easier to be obtained if the site became protected officially at county level at least, as a first step. The management we believe that it should be local with supervision from the county level. The involvement of voluntary bodies should also be considered (Burek 2008).

\subsection{Land zoning and land use planning of protected areas}

The problem of deciding the use of land in protected areas is still unresolved since actually there are no undisputable proofs about how a certain land use/zoning decision will influence the protected area (Nelson et al. 1997). 
Especially where tourism and economic activities are involved, a trade-off will be required, and the boundary of where these activities can harm or not the integrity of the protected area cannot be well defined (Blangy 1997; Varangu 1997).

Defining the extent of the protected area and the degree of human activity needs a careful investigation since the area is inhabited, and imposing strict restrictions can actually have opposite results, especially in rural and poor areas (Brockington and Wilkie 2015). A first step should be the study of the possibility to include the area in the existing system of protected areas (Kattan 2006). The closest protected area around the Costeşti is toward the northeast, the Sârca-Podu Iloaiei reservoirs $(\sim 5 \mathrm{~km})$, which is a SAC for avifauna. A connection with this protected area is hard to be created due to the topography and land use, but a possible future linkage through forested areas could be imagined for the Dealul Mare - Hârlău Site of Communitary Importance ( $20 \mathrm{~km}$ to the north).

In Fig. 10 we proposed the extension of two separate areas: (i) the area of the geoarchaeosite, around the present-day meander island, which can be easily protected and arranged since its area is a local public space and (ii) the area of the geosite, which should include the site of the Costeşti village. For the second area, we cannot propose yet specific measures until a further impact study on the local development potential is performed in order to estimate the impact of any protection measures. At least specific hydro-technical measures should be implemented in the geoarchaeosite space in order to stop the bank erosion, this being the easiest and the straightest path to follow for the protection of the geosite. The hydro-technical works need to be performed in such a way that the local landscape integrity is kept.

\section{Conclusions}

Costeşti archaeosite is an exemplary site of quaternary deposits and palaeogeographic evolution, unique in the Moldavian Plateau and Romania, which require geoconservation based on these values (Kiden et al. 1991). This status requires monitoring and management from the local, county, and national stakeholders and specific geoconservation measures. Bahluieț Valley at Costești village is a geoheritage site, containing an archaeosite, both an active and a passive geomorphosite, that has an "educational exemplarity", since multiples geomorphological processes can be reconstructed at various spatial and temporal scales (Pelfini and Bolatti 2014). Besides the fossil landslide, which is unique in Romania, the geoheritage site is a complex landslide that can be used to show the reactivation patterns of mass movement processes through retrogressive evolution at the entire hillslope level (Chorobak and Cebulski 2014), and the fluvial incision and deposition which is very well exemplified, both by morphology and stratigraphy. We propose to use the site as a study case for the hillslope and fluvial geomorphology courses at the bachelor's degree level.

The value of the site is given by the presence of Quaternary landslides, Quaternary deposits, Quaternary fluvial geomorphology, and archaeological heritage. Despite its archaeologic status and geoheritage value, the site is not included in a protected area or in a touristic network. Given the accessibility of the location from the national road between Iași and Paşcani, if proper arrangement and signaling are performed, the site can be included in the local and national geotouristic network (Newsome and Dowling 2006; Chen et al. 2015). Because of this new extended status, this geoheritage site needs to be protected, through multidisciplinary management, by understanding the natural 
processes governing those systems (Sharpless 2002) and the anthropic modifications in order to be able to: (i) understand how the natural processes respond to anthropic (Niculiţă, 2020b) and climate change disturbance (Niculiţă, 2020a); (ii) to determine the thresholds of natural and anthropic disturbances beyond which unacceptable acceleration of natural rates and magnitudes of change will occur (Niculiţă and Mărgărint, 2018), and (iii) to identify management options and measures which can be used to keep the disturbances below acceptable thresholds (Niculiţă, 2018).

Nowadays, the river is eroding the mound, and immediate protection measures are needed in order to limit the destruction of such an important deposit and morphology. At the same time, a management plan is needed to promote the site at local, regional, and national levels. Further scientific investigations are needed and can increase its value.

\section{Acknowledgments}

This work was supported by a grant of the "Alexandru Ioan Cuza" University of Iasi, within the Research Grants program, Grant UAIC, code GI-UAIC-2017-07. I wish to thank Bobi Apăvăloaiei and Virgil Băbîi from Iași County Directorate for Culture for the approval of OSL sampling and to György Sipos from Department of Physical Geography and Geoinformatics, Szeged University, for the OSL dating. I gratefully thank my colleagues Mihai Ciprian Mărgărint, Nicușor Necula, and Valeriu Stoilov-Linu, for their help in the fieldwork. I thank archaeologists Sergiu Enea and Dumitru Boghean for the approval of the use of the images from Fig. 8 and 9.

\section{References}

1) Alexandrowicz S, Margielewski W (2010) Impact of mass movements on geo- and biodiversity in the Polish Outer (Flysch) Carpathians. Geomorphology 123:290-304. https://doi.org/10.1016/j.geomorph.2010.07.020

2) Appleton M (2010) Protected area management planning in Romania. A manual and toolkit. Fauna \& Flora International, 83 p. http://www-old.anpm.ro/upload/5944_anpm_Ghid_Appleton.pdf

3) Bandyopadhyay S, Humavindu M, Shyamsundar P, Wang L (2009) Benefits to local communities from community conservancies in Namibia: an assessment. Development Southern Africa 26(5):733-754. https://doi.org/10.1080/03768350903303324

4) Biderman A, Bosak W (1997) Environmental education in protected areas as a contribution to heritage conservation, tourism and sustainable development. In: Nelson JG, Serafin R (eds) National parks and protected areas: keystones to conservation and sustainable development, NATO ASI Series, Vol. G 40. Springer-Verlag Berlin Heidelberg, pp 93-102. https://doi.org/10.1007/978-3-642-60907-7_ 8

5) Blangy S (1997) The Berezinski Biosphere Reserve in Belarus: Is Ecotourism a Tool to Support Conservation in the Reserve? In: Nelson JG, Serafin R (eds) National parks and protected areas: keystones to conservation and sustainable development, NATO ASI Series, Vol. G 40. Springer-Verlag Berlin Heidelberg, pp 191-194. https://doi.org/10.1007/978-3-642-60907-7_18

6) Boghian D (2009) Costești-Cier. În: Lazarovici C-M, Lazarovici G, Țurcanu S (eds) Cucuteni. A Great Civilization of the Prehistoric World, Editura Palatul Culturii, Iași, pp 98-99. 
7) Boghian D (2012) Unele observații cu privire la vasele cucuteniene de tip kernos/pseudo-kernos. Memoria Antiquitatis 28:39-63. (in Romanian)

8) Boghian D, Enea SC, Părpăuţă T, Tencariu FA, Vornicu DM, Asăndulesei A, Gania S., Vornicu A, Furnică RG, Munteanu B (2013) 109B. Costești, com. Costești, jud. Iași, Punct: Cier/Lângă Școală. In: Cronica Cercetărilor Arheologice din România. Campania 2012, pp 199-200. (in Romanian)

9) Boghian D, Ignătescu S, Enea SC, Ignat I., Tencariu FA, Vornicu DM, Vornicu A, Furnică RG, Părpăuţă T (2014a) Costești, com. Costești, jud. Iași, Punct: Cier/Lângă Școală. In: Cronica Cercetărilor Arheologice din România. Campania 2013, pp 204-206. (in Romanian)

10)Boghian D, Enea S-C, Pîrnău R-D, Secu C (2014b) Elemente de Landscape Archaeology în zona siturilor CosteștiCier și Giurgești-Dealul Mănăstirii, jud. Iași [Elements of landscape archaeology in the area of Costești-Cier and Giurgești - Dealul Mănăstirii sites, Iași county]. In: ArheoVest II2 - In honorem Gheorghe Lazarovici Interdisciplinaritate în Arheologie. JATEPress Kiadó, Szeged, pp 571-611 (in Romanian)

11)Boghian D, Enea S-C, Ignătescu S, Bejenaru L, Stanc S-M (2014c) Comunităţile cucuteniene din zona Târgului Frumos. Cercetări interdisciplinare în siturile de la Costeşti şi Giurgeşti. Alexandru Ioan Cuza University Press, Iaşi. (in Romanian)

12) Boghian D, Ignătescu S, Enea S-C, Pîrnău R, Vornicu D-M, Secu C, Furnică R-G, Vornicu A (2015) 116. Costești, com. Costești, jud. Iași. Punct: Cier/Lângă Școală. In: Cronica Cercetărilor Arheologice din România. Campania 2014, Institutul Naţional al Patrimoniului, București, pp 195-198. (in Romanian)

13)Boghian D, Ignătescu S, Enea S-C, Stigleț D-I, Kovács A (2016) 121. Costești, com. Costești, jud. Iași, Punct: Cier/Lângă Școală. In: CCAR. Campania 2015, Institutul Naţional al Patrimoniului, București, pp 224-225. (in Romanian)

14) Boghian D, Ignătescu S, Enea S-C, Stigleţ D-I, Baran V (2017) 127. Costeşti. Com. Costeşti, jud. Iaşi, Punct: Cier/Lângă Şcoală. In: Cronica Cercetărilor Arheologice din România. Campania 2016, Institutul Naţional al Patrimoniului, București, pp 229-231. (in Romanian)

15)Brockington D, Wilkie D (2015) Protected areas and poverty. Philos Trans R Soc Lond B Biol Sci 370(1681):20140271. https://doi.org/10.1098/rstb.2014.0271

16)Brown, J., Mitchell, B., 1997, Extending the reach of national parks and protected areas: local stewardship initiatives. In: Nelson JG, Serafin R (eds) National parks and protected areas: keystones to conservation and sustainable development, NATO ASI Series, Vol. G 40. Springer-Verlag Berlin Heidelberg, pp 103-116. https://doi.org/10.1007/978-3-642-60907-7_9

17)Burek CV (2008) The role of the voluntary sector in the evolving Geoconservation movement. In: Burek CV, Prosser CD (eds) The history of geoconservation. Geological Society London, Special Publications 300, London, pp 61-90. https://doi.org/10.1144/SP300.6

18)Buylaert JP, Jain M, Murray A S, Thomsen KJ, Thiel C, Sohbati R (2012) A robust feldspar luminescence dating method for Middle and Late Pleistocene sediments. Boreas 41(3):435-451. https://doi.org/10.1111/j.1502$\underline{3885.2012 .00248 . \mathrm{X}}$

19) Chen A, Lu Y, Ng YCY (2015) The principles of geotourism. Springer Geography, Springer, Berlin 
20)Chrobak A, Cebulski J (2014) Landslide in the Polish Carpathians as the Potential Educational Geosites. Current Issues of Tourism Research 4(1):38-49. http://citr.up.krakow.pl/article/view/1720

21)Ciurea V (1938) Contribuțiuni la preistoria Jud. Baia. Staţiunea Costești [Contributions to the prehistory of Baia County. Costești station]. Muzeul Fălticenilor, 11 p. (in Romanian)

22)Cobălcescu G (1883) Studii geologice și paleontologice asupra unor terenuri terțiare din unele părți ale României [Geological and paleontological studies on some tertiary lands from some parts of Romania]. Memoriile Geologice ale Școlii Militare din Iaşi, București. (in Romanian)

23) Cohen KM, Finney SC, Gibbard PL, Fan J-X (2013; updated) The ICS International Chronostratigraphic Chart. Episodes 36:199-204. https://doi.org/10.18814/epiiugs/2013/v36i3/002

24)Cohen KM, Gibbard PL (2019) Global chronostratigraphical correlation table for the last 2.7 million years. Quat Int 500:20-31. https://doi.org/10.1016/j.quaint.2019.03.009

25)Comănescu L, Nedelea A (2017) Geomorphosites assessments of the glacial and periglacial landforms from Southern Carpathians. In: Rădoane M, Vespremeanu-Stroe A (eds) Landform Dynamics and Evolution in Romania. Springer, pp 215-246. https://doi.org/10.1007/978-3-319-32589-7_10

26)Conrad, O., Bechtel, B., Bock, M., Dietrich, H., Fischer, E., Gerlitz, L., Wehberg, J., Wichmann, V., and Böhner, J. (2015) System for Automated Geoscientific Analyses (SAGA) v. 2.1.4, Geosci Model Dev 8:1991-2007. https://doi.org/10.5194/gmd-8-1991-2015

27)Crofts, R., Gordon, J.E., Brilha, J., Gray, M., Gunn, J., Larwood, J., Santucci, V.L., Tormey, D., Worboys, G.L. (2020). Guidelines for geoconservation in protected and conserved areas. Best Practice Protected Area Guidelines Series No. 31. Gland, Switzerland: IUCN. https://doi.org/10.2305/IUCN.CH.2020.PAG.31.en

28)Cruden DM, Varnes DJ (1996) Landslide types and processes. In: Turner AK, Schuster RL (eds) Landslides investigation and mitigation, transportation research board, US National Council, special report 247, Washington, DC, Chapter 3, pp 36-75.

29)Davis WM (1906) Incised meandering valleys. The Bulletin of the Geographical Society of Philadelphia, 4(4):182192.

30)Davis WM (1913) Meandering Valleys and Underfit Rivers. Annals of the Association of American Geographers 3:3-28. https://doi.org/10.2307/2560688

31)Davies T (2015) Landslide Hazards, Risks, and Disasters: Introduction. In: Shroder JF, Davies T (eds.) Landslide Hazards, Risks, and Disasters, Elsevier, pp 1-16. https://doi.org/10.1016/B978-0-12-396452-6.00001-X

32)De Leeuw A, Vincent SJ, Matoshko A, Matoshko A, Stoica M, Nicoară I (2020) Late Miocene sediment delivery from the axial drainage system of the East Carpathian foreland basin to the Black Sea. Geology 48:761-765. https://doi.org/10.1130/G47318.1

33)Dingwall P, Weighell T, Badman T (2005) Geological World Heritage: a global framework. A contribution to the Global Theme Study of World Heritage Natural Sites. IUCN, IUCN-Rep-2005-009. $\underline{\text { https://portals.iucn.org/library/sites/library/files/documents/Rep-2005-009.pdf }}$ 
34)Dumitroaia G (2000) Comunități preistorice din nord-estul României (de la cultura Cucuteni până la bronzul mijlociu) (Prehistoric communities from Northeast Romania from Cucuteni Culture to the Bronze Age). Muzeul de Istorie Piatra Neamț, Piatra Neamț. (in Romanian)

35) Dunlop L, Larwood JG, Burek CV (2018) Geodiversity action plans - a method to facilitate, structure, inform and record action for geodiversity. In: Reynard E, Brilha J (eds) Geoheritage. Assessment, protection and management. Elsevier, pp 53-65. https://doi.org/10.1016/B978-0-12-809531-7.00003-4

36) Dury GH (1964) Principles of underfit streams. U.S. Geol. Survey, Prof. Paper 452-A, U.S. Government Printing Office, Washington. https://doi.org/10.3133/pp452A

37)Dury GH (1965) Theoretical implications of underfit streams. U.S. Geol. Survey, Prof. Paper 452-C, U.S. Government Printing Office, Washington. https://doi.org/10.3133/pp452C

38)Ellis NV, Bowen DQ, Campbell S, Knill JL, McKirdy AP, Prosser CD, Vincent MA, Wilson RCL (1996) An introduction to the geological conservation review. GCR Series No. 1, Joint Nature Conservation Committee, Peterborough.

39) Emerton L (2001) The nature of benefits and benefits of nature: Why wildlife conservation has not economically benefited communities in Africa. In: Hulme D, Murphree M (eds) African Wildlife and Livelihoods: The promise and performance of community conservation. James Curry Ltd, Oxford, pp. 208-226. https://www.cbd.int/financial/values/g-benefitsafricamunity-iucn.pdf

40)Enea S-C, Boghian D, Ignătescu S (2016) Anthropomorphic and zoomorphic representations from the Cucuteni sites of Giurgești and Costești (Iași County, Romania). In: Cucuteni Culture within the European neo-eneolithic context, Proceedings of the International Colloquium "CUCUTENI - 130" 15-17 October 2014, Piatra-Neamț, Romania, Constantin Matasă Press, Piatra Neamț, pp 533-580.

41)Erikstadt L. (1999). A holistic approach to secure geoconservation in local physical planning, In: Barettino D, Vallejo M, Gallego E (eds) Towards the Balanced Management and Conservation of the Geological Heritage in the New Millennium, Sociedad Geologic de España, Madrid, pp 69-72.

42) Galbraith RF, Roberts RG, Laslett GM, Yoshida H, Olley JM, (1999). Optical dating of single and multiple grains of quartz from Jinmium Rock Shelter, northern Australia: Part 1, experimental design and statistical models. Archaeometry 41: 339-364. https://doi.org/10.1111/j.1475-4754.1999.tb00987.x

43) Gania S, Asăndulesei A, Romanescu G (2012) Monitorizarea proceselor hidromorfologice în cazul siturilor arheologice. Studiu de caz: așezarea cucuteniană de la Costești-Cier, jud. Iași. In: Al III-lea Simpozion Arheoinvest Arheologia și politicile de protejarea a patrimoniului cultural, 2-3 noiembrie 2012, Iași, România, pp 11-12. (in Romanian)

44)Gordon JE (2016) Geoheritage case study: geotourism and geoparks in Scotland. In: Hose TA (ed), Geoheritage and Geotourism: a European Perspective. The Boydell Press, Woodbridge, Suffolk, pp 261-278.

45)Gordon JE (2019) Geoconservation principles and protected area management. International Journal of Geoheritage and Parks 7(4):199-210. https://doi.org/10.1016/j.ijgeop.2019.12.005 
46)Gordon JE, Crofts R, Díaz-Martínez E (2018a) Chapter 12 - Geoheritage Conservation and Environmental Policies: Retrospect and Prospect. In: Reynard E, Brilha J (eds) Geoheritage Assessment, Protection, and Management, Elsevier, pp 213-235. https://doi.org/10.1016/B978-0-12-809531-7.00012-5

47)Gordon JE, Crofts R, Díaz-Martínez E, Woo KS (2018b) Enhancing the Role of Geoconservation in Protected Area Management and Nature Conservation. Geoheritage 10:191-203. https://doi.org/10.1007/s12371-017-0240$\underline{5}$

48) Gray M (2004). Geodiversity: valuing and conserving abiotic nature, Chichester, Wiley.

49) Gray M (2019) Geodiversity, geoheritage and geoconservation for society. International Journal of Geoheritage and Parks 7(4):226-236. https://doi.org/10.1016/j.ijgeop.2019.11.001

50)Infield M (2001) Cultural Values: a Forgotten Strategy for Building Community Support for Protected Areas in Africa. Conservation Biology 15(3):800-802. https://doi.org/10.1046/j.1523-1739.2001.015003800.x

51) Ionesi L, Ionesi B, Roșca L, Lungu A, Ionesi V (2005) Sarmațianul mediu și superior de pe Platforma Moldovenească [The medium and upper Sarmatian from Moldavian Platform]. Editura Academiei Române, Bucharest. (in Romanian)

52) Jaboyedoff M, Baillifard F, Couture R, Locat J, Locat $P$ (2004) Toward preliminary hazard assessment using DEM topographic analysis and simple mechanic modeling. In: Lacerda WA, Ehrlich M, Fontoura AB, Sayo A (eds), Landslides Evaluation and stabilization. Balkema, pp 191-197.

53) Jaboyedoff M, Daicz S, Derron M-H, Penna I, Rudaz B (2013) Defining the volume and geometry of the landslide failure surfaces: a review with emphasis on the Sloping Local Base Level (SLBL). Geophysical Research Abstracts 15 EGU2013-9431.

54) Jones RW, Simmons MD (1997) A review of the stratigraphy of eastern Paratethys (Oligocene-Holocene), with particular emphasis on the Black Sea. In: Robinson AG (ed), Regional and petroleum geology of the black Sea and surrounding region: AAPG Memoir 68, p 39-52.

55)Kattan G (2006) Reconciling Theory and Practice in Designing a Regional Reserve System. A Colombian Case Study. In: Groom MJ, Meffe GK, Carol CR (eds), Principles of Conservation Biology, Sinauer Associates Inc., Sunderland MA, pp 546-549.

56)Korup O, Schlunegger F (2007) Bedrock landsliding, river incision, and transience of geomorphic hillslopechannel coupling: Evidence from inner gorges in the Swiss Alps. J Geophys Res: Earth Surf 112(F3):1-19. https://doi.org/10.1029/2006JF000710

57) Lapeyre R (2010) Community-based tourism as a sustainable solution to maximise impacts locally? The Tsiseb Conservancy case, Namibia. Development Southern Africa 27(5):757-772. https://doi.org/10.1080/0376835X.2010.522837

58) Larsen IJ, Montgomery DR (2012) Landslide erosion coupled to tectonics and river incision. Nat Geosci 5:468-

\section{3. https://doi.org/10.1038/ngeo1479}

59) Lima EA, Lima AF, Brilha J, Calado $H$, Nunes JC (2013) Integration of the geoheritage management in environmental and land-use policies. Rendiconti Online Societa Geologica Italiana 28:102-105. 
60) Liritzis I, Stamoulis K, Papachristodoulou C, Ioannides K (2013) A reevaluation of radiation dose-rate conversion factors. Mediterranean Archaeology and Archaeometry 13(3):1-15. http://maajournal.com/Issues/2013/Vol133/01.pdf

61) Mărgărint MC, Niculiţă M (2017) Landslide type and pattern in Moldavian Plateau, NE Romania. In: Rădoane M, Vespremeanu-Stroe A (eds) Landform Dynamics and Evolution in Romania. Springer, pp 271-304. https://doi.org/10.1007/978-3-319-32589-7_12

62) Macarovici N, Turculeţ L (1956) Geologia regiunii Ruginoasa-Hărmăneşti-Vaşcani-Costeşti (Raionul Tg. Frumos). Analele știinţifice ale Universităţii Al. I. Cuza din Iaşi (serie nouă), Secţiunea II (Ştiinţe Naturale), 2(1):288-295. (in Romanian)

63) Mansourian S, Higgins-Zogib L, Dudley N, Stolton S (2008) Poverty and protected areas. In: Protected Areas in today's world: their values and benefits for the welfare of the planet, BCD Technical Series No. 36, UNEP, pp 1828. https://www.cbd.int/doc/publications/cbd-ts-36-en.pdf

64) Mantu C-M (1998) Cultura Cucuteni. Evoluție, cronologie, legături (The Cucuteni Culture. Evolution, chronology, links). Muzeul de Istorie Piatra Neamț, Piatra Neamt, (in Romanian).

65) Mantu C-M (2000) Cucuteni-tripolye cultural complex: relations and synchronisms with other contemporaneous cultures from the Black sea area. Studia Antiqua et Archaeologica 7:11-27.

66) Margielewski W (2010) Records of the Late Glacial-Holocene palaeoenvironmental changes in landslide forms and deposits of the Beskid Makowski and Beskid Wyspowy Mountains area (Polish Outer Carpathians). Folia Quaternaria 76, Krakow.

67) Matasă C (1940) Deux stations à céramique peinte de Moldavie. Dacia, 7-8:69-84.

68) Mateescu C-N (1940) O nouă staţiune preistorică din cercul ceramicii pictate: Costești-Baia (A new prehistoric station from the painted ceramic circle: Costești-Baia). Revista de preistorie și antichități naționale 2-4:63-69. (in Romanian)

69) MacDonald A (1990) Surface erosion and disturbance at archaeological sites: implications for site preservation. Miscellaneous Paper EL-90-6, US Army Engineer Waterways Experiment Station, Vicksburg, MS. https://apps.dtic.mil/dtic/tr/fulltext/u2/a219619.pdf

70) Monteleone S, Sabatino M (2014) Hydrogeological hazards and weather events: triggering and evolution of shallow landslides. International Soil and Water Conservation Research 2(2):23-29. https://doi.org/10.1016/S2095-6339(15)30003-4

71) Murray AS, Wintle AG (2000) Luminescence dating using an improved single-aliquot regenerative-dose protocol. Radiat Meas 32(1):57-73. https://doi.org/10.1016/S1350-4487(99)00253-X

72) Murray AS, Wintle AG (2003) The single aliquot regenerative dose protocol: Potential for improvements in reliability. Radiat Meas 37(4):377-381. https://doi.org/10.1016/S1350-4487(03)00053-2

73) Nelson G, Serafin R, Skibicki A, Lawrence P (1997) Land use and decision-making for national parks and protected areas. In: Nelson J G and Serafin R (eds) National parks and protected areas: keystones to conservation and sustainable development, NATO ASI Series, Vol. G 40. Springer-Verlag Berlin Heidelberg, pp 43-63. https://doi.org/10.1007/978-3-642-60907-7_5 
74) Newsome D, Dowling R (2006) The scope and nature of geotourism. In: Dowling RK, Newsome D (eds) Geotourism. Elsevier Butterworth-Heinemann, Oxford, pp 3-25. https://doi.org/10.1016/B978-0-7506-62154.50009-9

75)Niculiţă M (2011) A landform classification schema for structural landforms of the Moldavian platform (Romania). In: Hengl T, Evans IS, Wilson JP, Gould M (eds) Geomorphometry, Redlands, CA, pp 129-132.

76)Niculiță M (2018) Bahluieț Valley at Costești village (Romania) geoarchaeosite: the need for its protecting, promoting and managing. In: E. Głowniak, A. Wasiłowska, P. Leonowicz (Eds), Geoheritage and Conservation: Modern Approaches and Applications Towards the 2030 Agenda. 9th ProGEO Symposium, Chęciny, Poland, 2528th June 2018 Programme and Abstract Book, p 166. Faculty of Geology, University of Warsaw.

77)Niculiţă M (2020a) Landslide hazard induced by climate changes in North-Eastern Romania. In: Leal Filho W, Nagy G, Borga M, Chávez Muñoz D, Magnuszewsk A (eds) Climate Change, Hazards and Adaptation Options, Climate Change Management, Springer, Cham, pp 245-265. https://doi.org/10.1007/978-3-030-37425-9 13

78)Niculiță M (2020b) Evaluarea activității alunecărilor de teren din Podișul Moldovei în holocen şi antropocen: element fundamental pentru evaluarea hazardului la alunecări de teren în contextul schimbărilor climatice (LAHAMP). Raport de cercetare [Assessment of landslide activity in the Moldavian Plateau in the Holocene and Anthropocene: a fundamental element for assessing the risk of landslides in the context of climate change (LAHAMP)]. Editura Tehnopress, Iași. (in Romanian)

79) Niculiță M, Mărgărint MC, Santangelo M (2016a) Archaeological evidence for Holocene landslide activity in the Eastern Carpathian lowland. Quat Int 415:175-189. https://doi.org/10.1016/j.quaint.2015.12.048

80)Niculiță M, Mărgărint MC, Santangelo M (2016b) Pleistocene landslides in the Moldavian Plateau, Eastern Romania. Georeview. http://dx.doi.org/10.4316/GEOREVIEW.2016.0.0.341

81)Niculiță M, Mărgărint MC, Cristea IA (2017) Relict landslides, fluvial landforms and threatened geoheritage Costești village. In: Niculiţă M, Mărgărint MC (eds) Proceedings of Romanian Geomorphology Symposium, vol. 1, 11-14 May 2017, Alexandru Ioan Cuza University of Iași Press, pp 130-132. https://doi.org/10.15551/prgs.2017.126

82) Niculiță M, Mărgărint MC (2018) Landslides and Fortified Settlements as Valuable Cultural Geomorphosites and Geoheritage Sites in the Moldavian Plateau, North-Eastern Romania. Geoheritage 10(4):613-634. https://doi.org/10.1007/s12371-017-0261-0

83)Niculiță M, Mărgărint MC, Cristea IA (2019) Using archaeological and geomorphological evidence for the establishment of a relative chronology and evolution pattern for Holocene landslides. PLoS ONE 14(12):e0227335. https://doi.org/10.1371/journal.pone.0227335

84)Niculiță M, Mărgărint MC, Tarolli P (2020) Chapter 10 - Using UAV and LiDAR data for gully geomorphic changes monitoring. In: Tarolli P, Mudd SM (eds) Remote Sensing of Geomorphology, Developments in Earth Surface Processes, vol. 23. Elsevier, pp 271-315. https://doi.org/10.1016/B978-0-444-64177-9.00010-2

85)Pánek T, Hartvich F, Jankovská V, Klimeš J, Tábořík P, Bubík M, Kapustová V, Hradecký J (2014) Large Late Pleistocene landslides from the marginal slope of the Flysch Carpathians. Landslides 11(6):981-992. $\underline{\text { https://doi.org/10.1007/s10346-013-0463-8 }}$ 
651

652

653

654

655

656

657

658

659

660

661

662

663

664

665

666

667

668

669

670

671

672

673

674

675

676

677

678

679

680

681

682

683

684

685

686

86) Pelfini M, Bollati I (2014) Landforms and geomorphosites ongoing changes: concepts and implications for geoheritage promotion. Quaestiones Geographicae 33(1):131-143. https://doi.org/10.2478/quageo-2014-0009

87) Pevzner MA, Vangengeim EA (1993) Magnetochronological age assignments of Middle and Late Sarmatian mammalian localities of the Eastern Paratethys. Newsletters on Stratigraphy 29:63-75. https://doi.org/10.1127/ $\underline{\operatorname{nos} / 29 / 1993 / 63}$

88) Phillips A (1997) Landscape approaches to national parks and protected areas. In: Nelson JG, Serafin R (eds) National parks and protected areas: keystones to conservation and sustainable development, NATO ASI Series, Vol. G 40. Springer-Verlag Berlin Heidelberg, pp 31-42. https://doi.org/10.1007/978-3-642-60907-7_4

89) Prescott JR, Hutton JT (1994) Cosmic ray contributions to dose rates for luminescence and ESR dating: large depths and long-term variations. Radiat Meas 23:497-500. https://doi.org/10.1016/1350-4487(94)90086-8

90) ProGEO (2011) Conserving our shared geoheritage - a protocol on geoconservation principles, sustainable site use, management, fieldwork, fossil and mineral collecting, PDF Document, 10 pp; http://www.progeo.se/progeoprotocoldefinitions-20110915.pdf. Accessed 30 December 2020

91)QGIS.org, 2021. QGIS Geographic Information System. QGIS Association. http://www.qgis.org

92) Railsback LB, Gibbard PL, Head MJ, Voarintsoa NRG, Toucanne S (2015) An optimized scheme of lettered marine isotope substages for the last 1.0 million years, and the climatostratigraphic nature of isotope stages and substages. Quat Sci Rev 111:94-106. https://doi.org/10.1016/j.quascirev.2015.01.012

93)Rich JL (1914) Certain Types of Stream Valleys and Their Meaning. J Geol 22(5):469-497. https://doi.org/10.1086/622164

94)Rögl F (1998) Palaeogeographic considerations for Mediterranean and Paratethys seaways (Oligocene to Miocene). Annalen des Naturhistorischen Museum in Wien 99:279-310. https://www.jstor.org/stable/41702129

95) Sharples C (2002) Concept and principles of geoconservation, PDF Document, Tasmanian Parks and Wildlife Service, p 79. www.dpiw.tas.gov.au/inter.nfs/webpages/SJON-57W4FD. Accessed 30 December 2020

96) Ştefan P, (1989) Geologia regiunii Dealului Mare-Hîrlău şi perspectivele în resurse minerale utile [The geology of Dealul Mare-Hîrlău region and the perspectives for mineral resources]. PhD thesis, Alexandru Ioan Cuza University of Iaşi. (in Romanian)

97)Thiel C, Buylaert J, Murray A, Terhorst B, Hofer I, Tsukamoto S, Frechen M (2011) Luminescence dating of the Stratzing loess profile (Austria) - Testing the potential of an elevated temperature post-IR IRSL protocol. Quat Int 234(1-2):23-31. https://doi.org/10.1016/j.quaint.2010.05.018

98) Tufescu V (1935) Observări asupra limitei de vest a Depresiunei Jijiei [Observation on the western limit of Jijia Depression]. Buletinul Societăţii Regale Române de Geografie 53:1-30. (in Romanian)

99) Tufescu V (1937a) Dealu Mare-Hîrlău (Observări asupra evoluţiei reliefului şi aşezărilor omeneşti) [Dealu MareHîrlău (Observations on the landform evolution and settlements)]. Buletinul Societăţii Regale Române de Geografie 56:48-215. (in Romanian)

100) Tufescu V (1937b) Observations geologiques sur les collines de Hârlău (Moldavie). Annales Scientifiques de L'Universite de Jassy, seconde partie, 24(1):108-133. 
101) van der Straaten J (1997) The Economic Pitfalls and Barriers of the Sustainable Tourism Concept in the Case of National Parks. In: Nelson JG, Serafin R (eds) National parks and protected areas: keystones to conservation and sustainable development, NATO ASI Series, Vol. G 40. Springer-Verlag Berlin Heidelberg, pp 81-91. https://doi.org/10.1007/978-3-642-60907-7_7

102) Varangu A (1997) A Clash of Values: Planning to Protect the Niagara Escarpment in Ontario, Canada. In: Nelson JG, Serafin R (eds) National parks and protected areas: keystones to conservation and sustainable development, NATO ASI Series, Vol. https://doi.org/10.1007/978-3-642-60907-7_6

103) Vulpe E (1944) Raport asupra săpăturilor din comuna Costeşti-Baia din August-Sptembrie 1943 [Report on the diggings from Costești-Baia commune on August-September 1943]. Raport asupra activității științifice a Muzeului național de Antichități în anii 1942 și 1943. "Bucovina” I.E. Torouțiu, Bucharest, pp 37-38. (in Romanian)

104) Woodley S (1997) Science and protected area management: an ecosystem-based perspective. In: Nelson JG, Serafin R (eds) National parks and protected areas: keystones to conservation and sustainable development, NATO ASI Series, Vol. G 40. Springer-Verlag Berlin Heidelberg, pp 11-21. https://doi.org/10.1007/978-3-642-60907-

105) Wintle AG, Murray AS (2006) A review of quartz optically stimulated luminescence characteristics and their relevance in single-aliquot regeneration dating protocols. Radiat Meas 41:369-391. https://doi.org/10.1016/j.radmeas.2005.11.001

106) Zaharia N, Petrescu-Dâmboviţa M, Zaharia E (1970) Aşezări din Moldova: de la paleolitic până în secolul al 709 


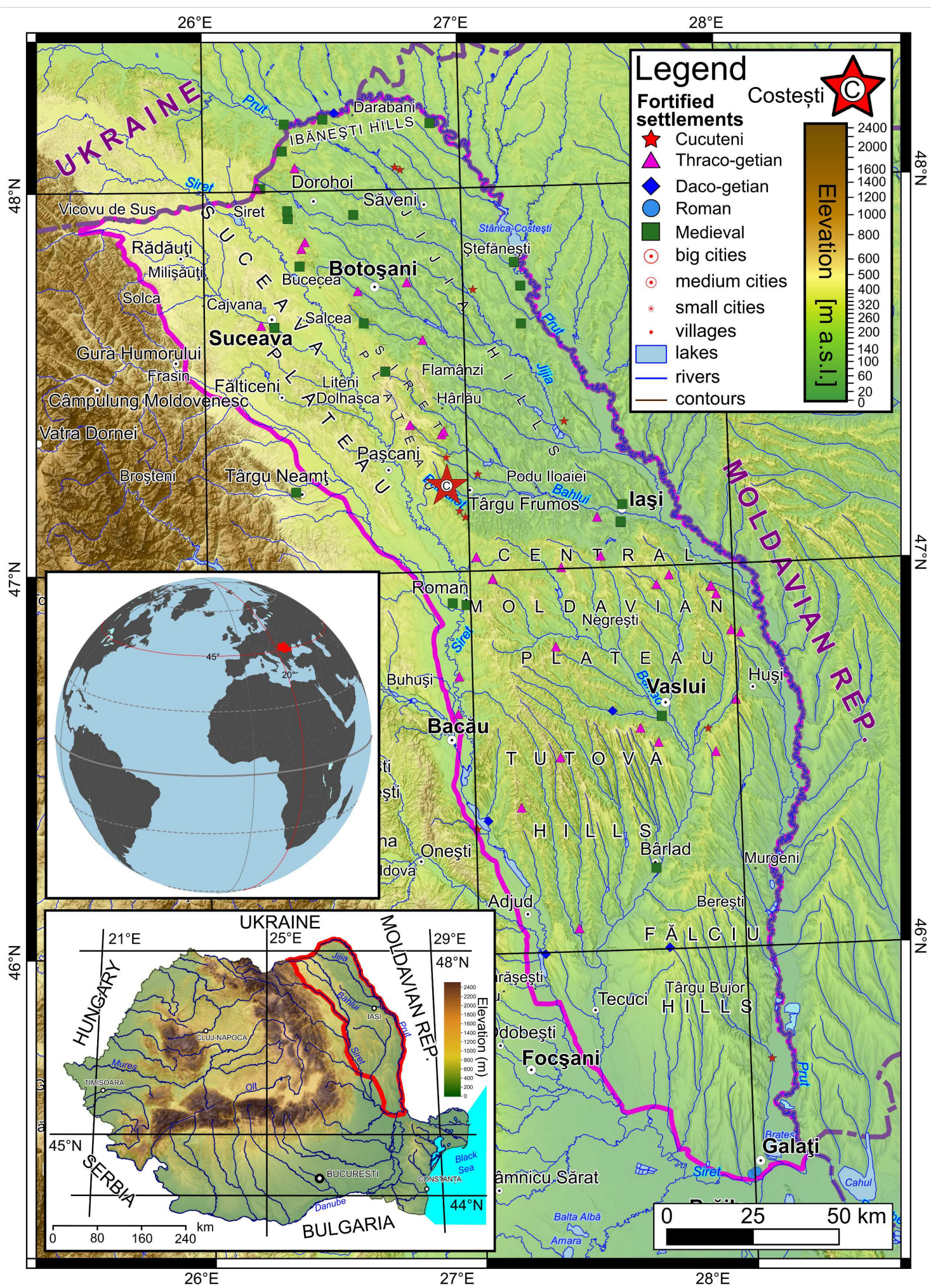

712 Figure 1 The geographic localization of the studied site within the Eastern Romania and the Moldavian Plateau. 


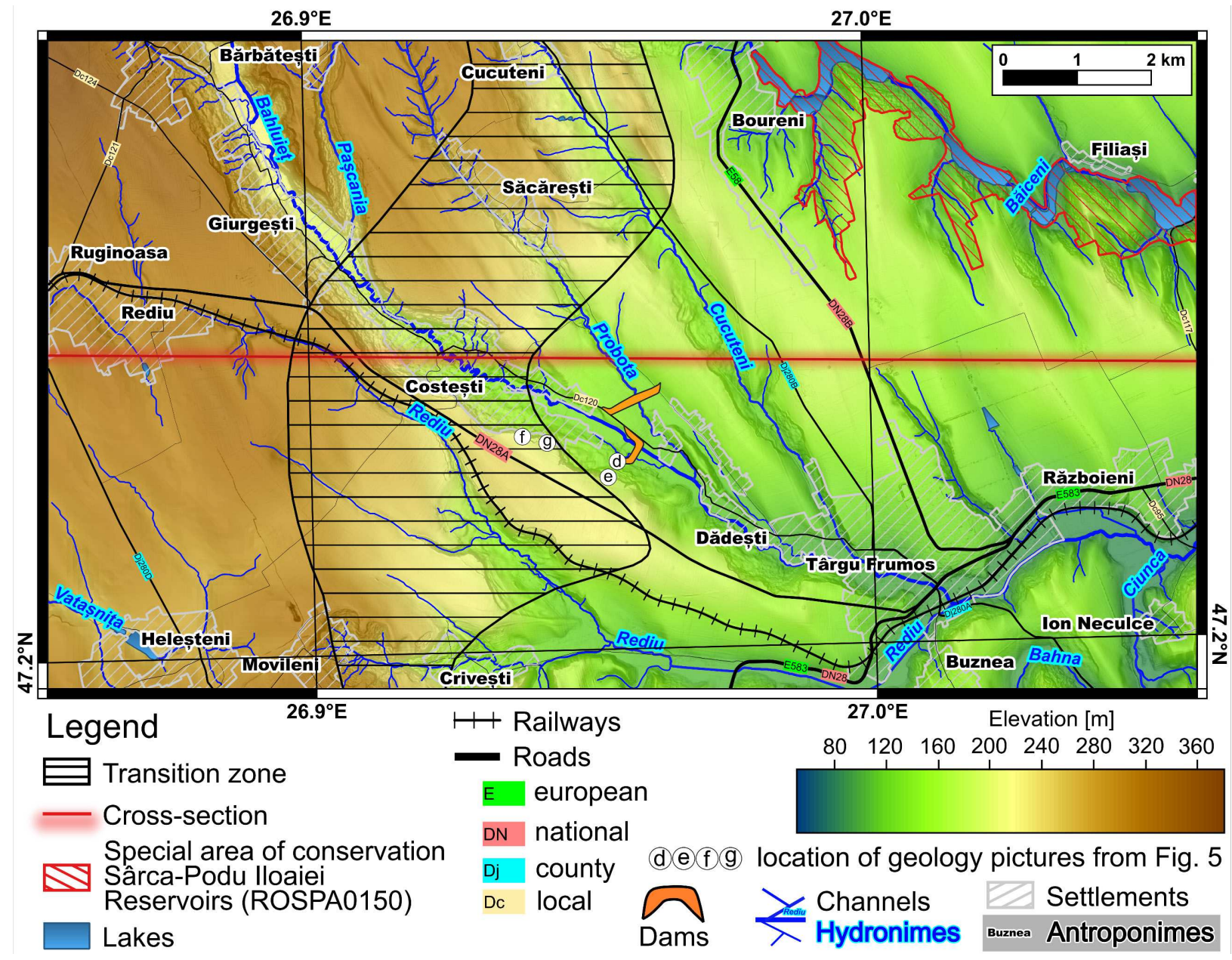

714 Figure 2 The location of the studied site at the transition zone between Siret Plateau and Jijia Hills. 


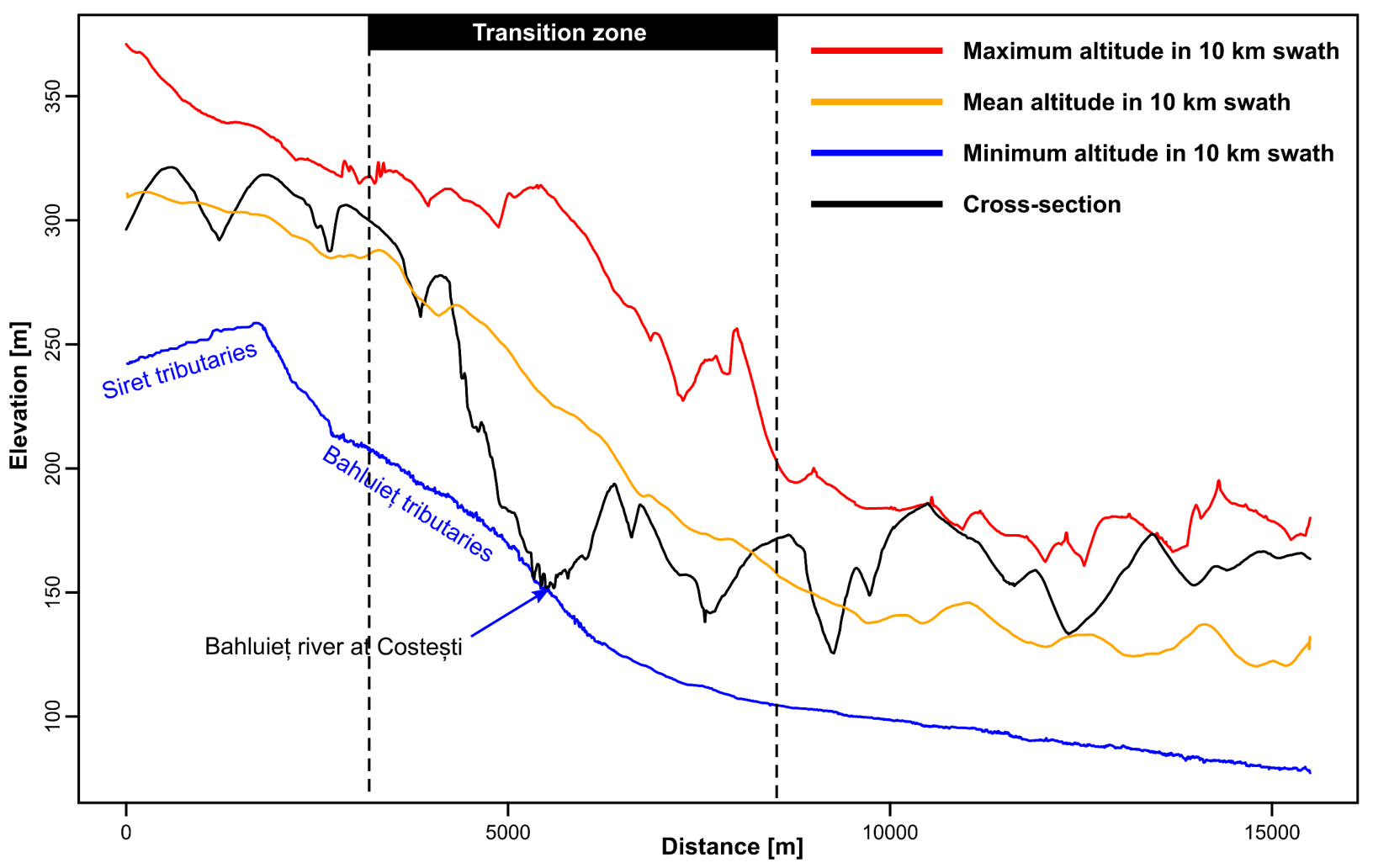

716 Figure 3 Swath cross-section (10 km wide) through the transition zone between Siret Plateau and Jijia Hills.

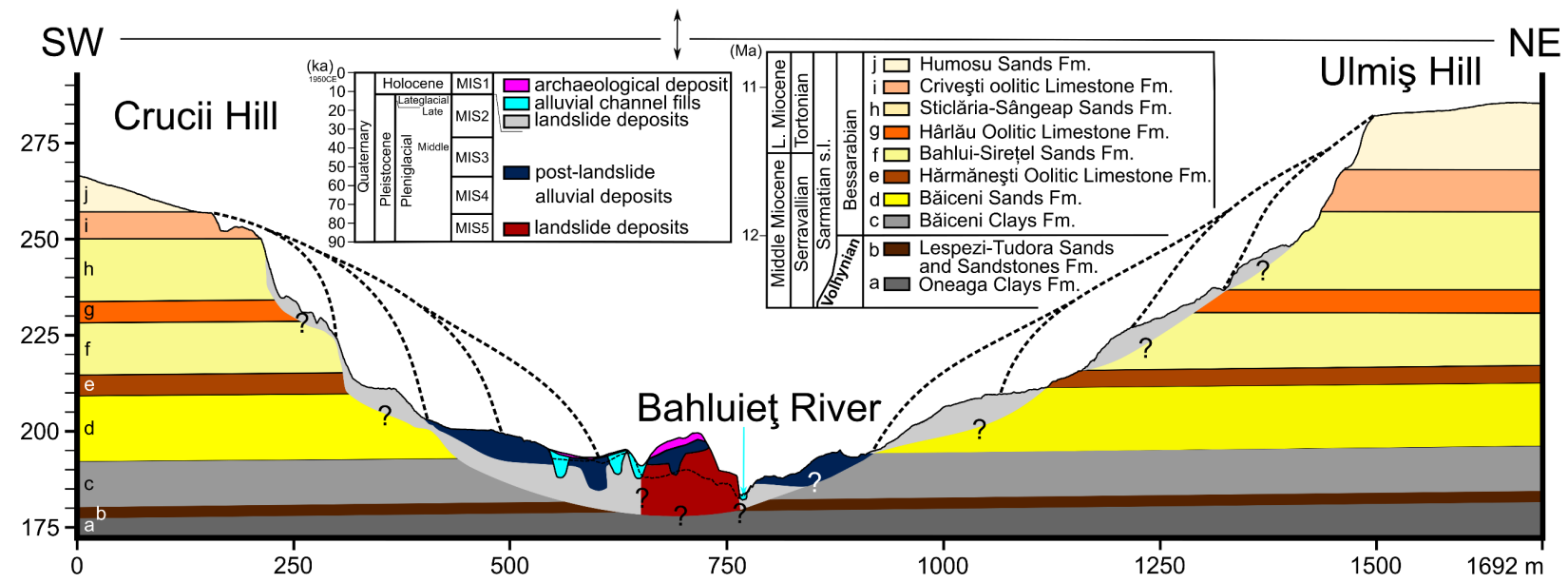

718 Figure 4 Cross-sectional geomorphological profile through Bahluieț Valley in the Costești - Cier site area interpreted based on geological data from Macarovici and Turculeț (1959), Ștefan (1989), fieldwork and Niculiță et al. 2017 ERT data; question marks show interpolated boundaries uncertain levels of lithological correlation; dashed lines indicate possible profiles of the hillslopes between landslide events. 

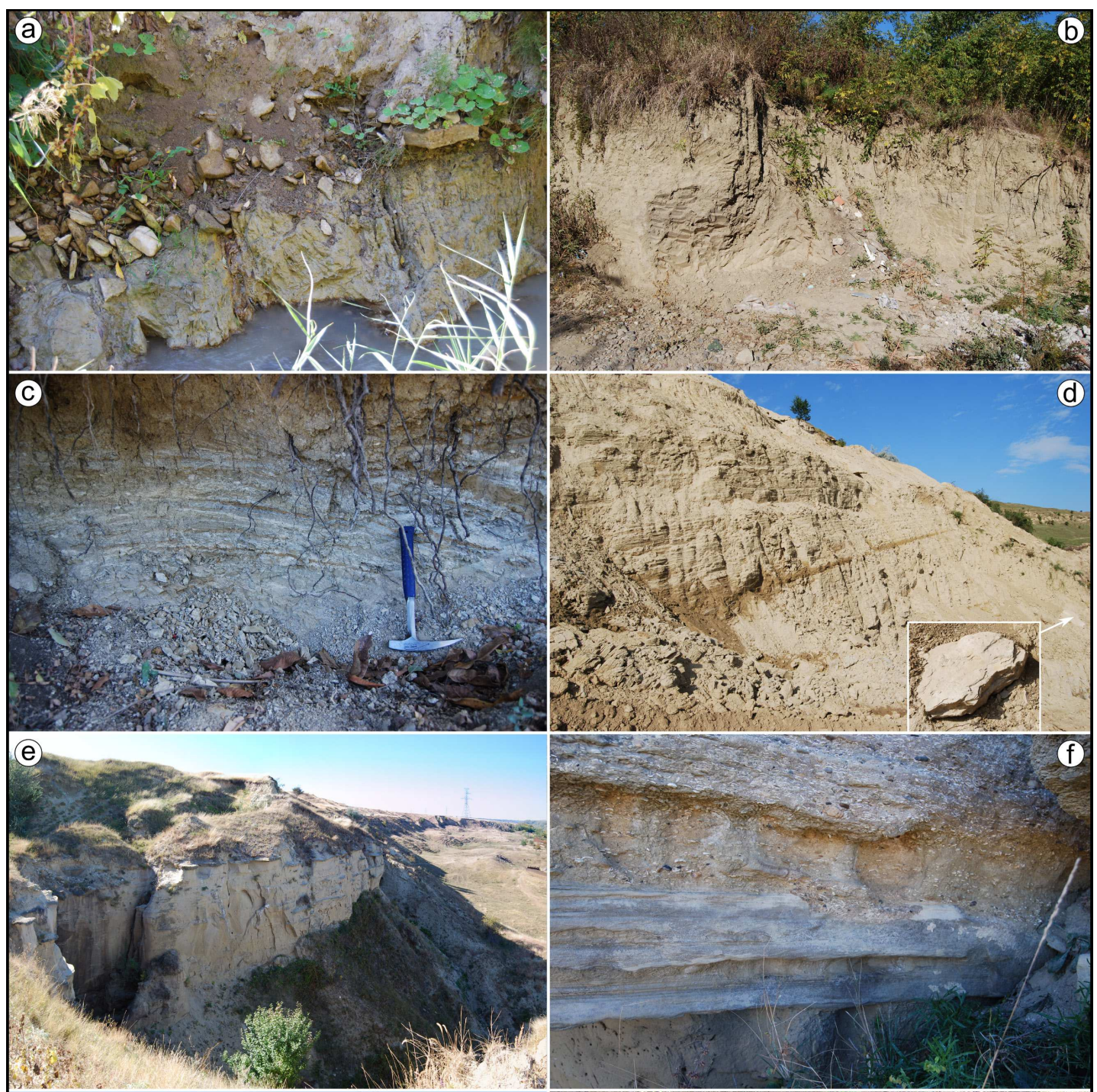

$$
\text { (g) }
$$

Figure 5 The geological formation identified in the field: a) overturned Oneaga Clays outcropping in the Bahluieț channel, b) Lespezi-Tudora Sands outcropping in the Bahluieț floodplain, c) Băiceni clays outcropping on the left hillslope in a quarry, d) Băiceni Sands outcropping in a quarry on the right hillslope, the inset showing a stone from the overlapping Hărmănești Oolitic Limestone, e) Bahlui Sirețel Sands outcropping in a gully bank on the right hillslope, f) Hârlău Oolitic Limestone outcropping in a landslide scarp on the 

Limestone outcropping in a gully on the scarp of the Costești landslide.

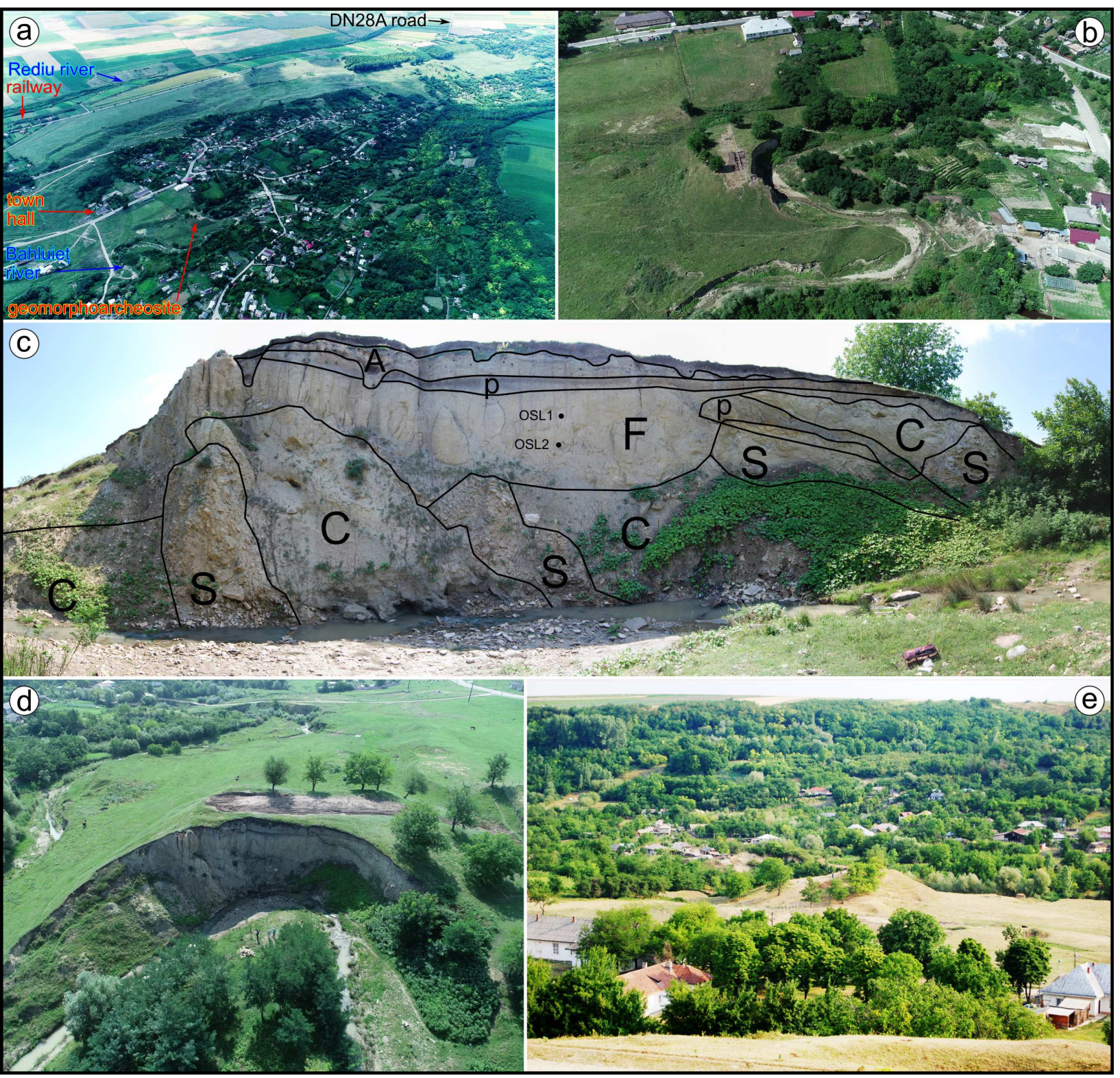

Figure 6 The environment of the geoheritage site Bahluieț Valley at Costești and of the Costești - Cier archaeological site: a) aerial view of the geoheritage site from the north-east, b) aerial view of the geomorfoarcheosite, c) view of the eroded bank with the stratigraphic situation ( $\mathrm{S}$ - sandstone, $\mathrm{C}$ - mudstone, $\mathrm{F}$ - loamy terrace deposit, p - paleosoil, A - archaeological deposit, OSL1 and 2 - the location of OSL samples), d) aerial view of the meander island eroded bank, e) view of the meander island from above the Costești town hall. 


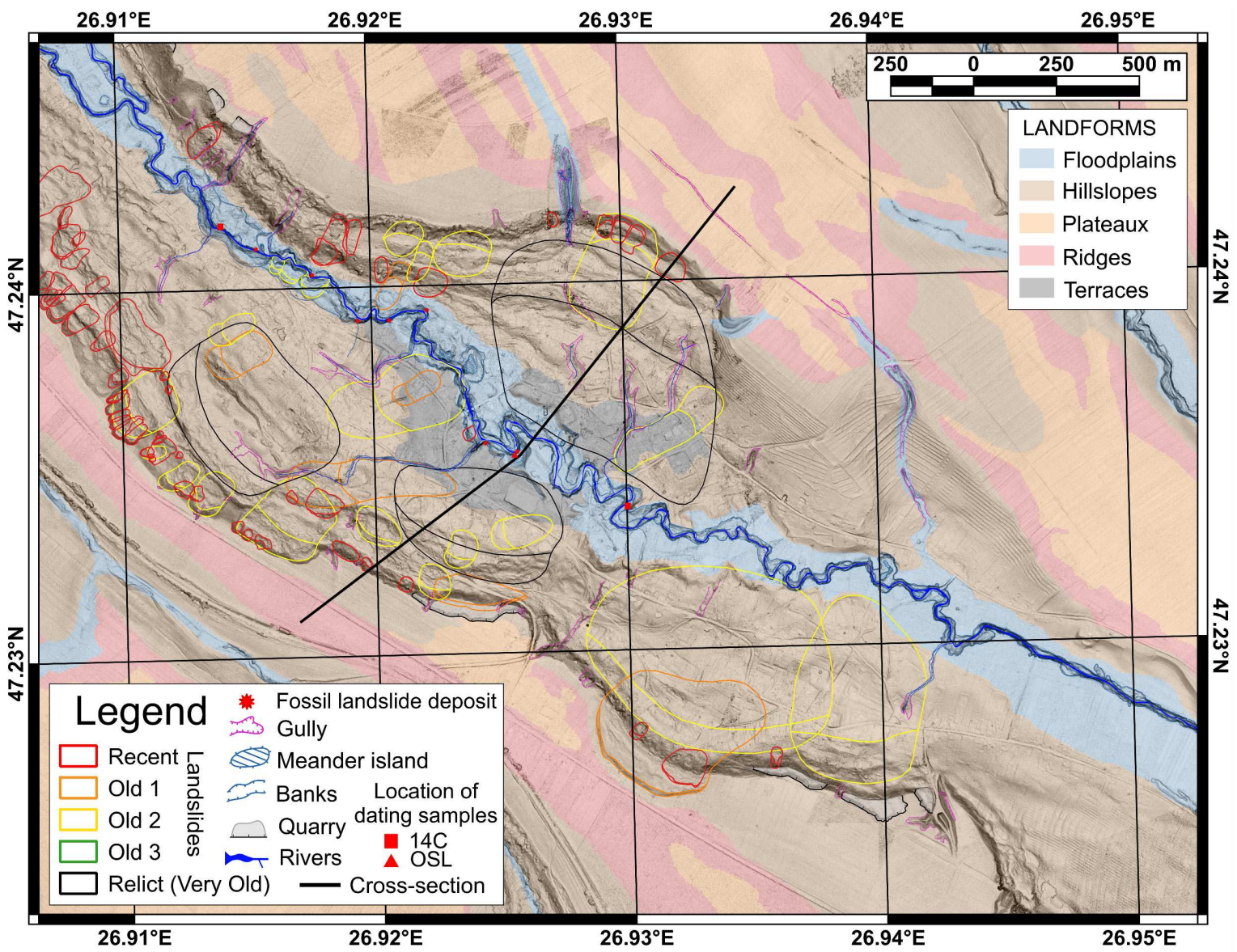

737 Figure 7 The geomorphological map of Bahluieț Valley at Costești geoheritage site. 


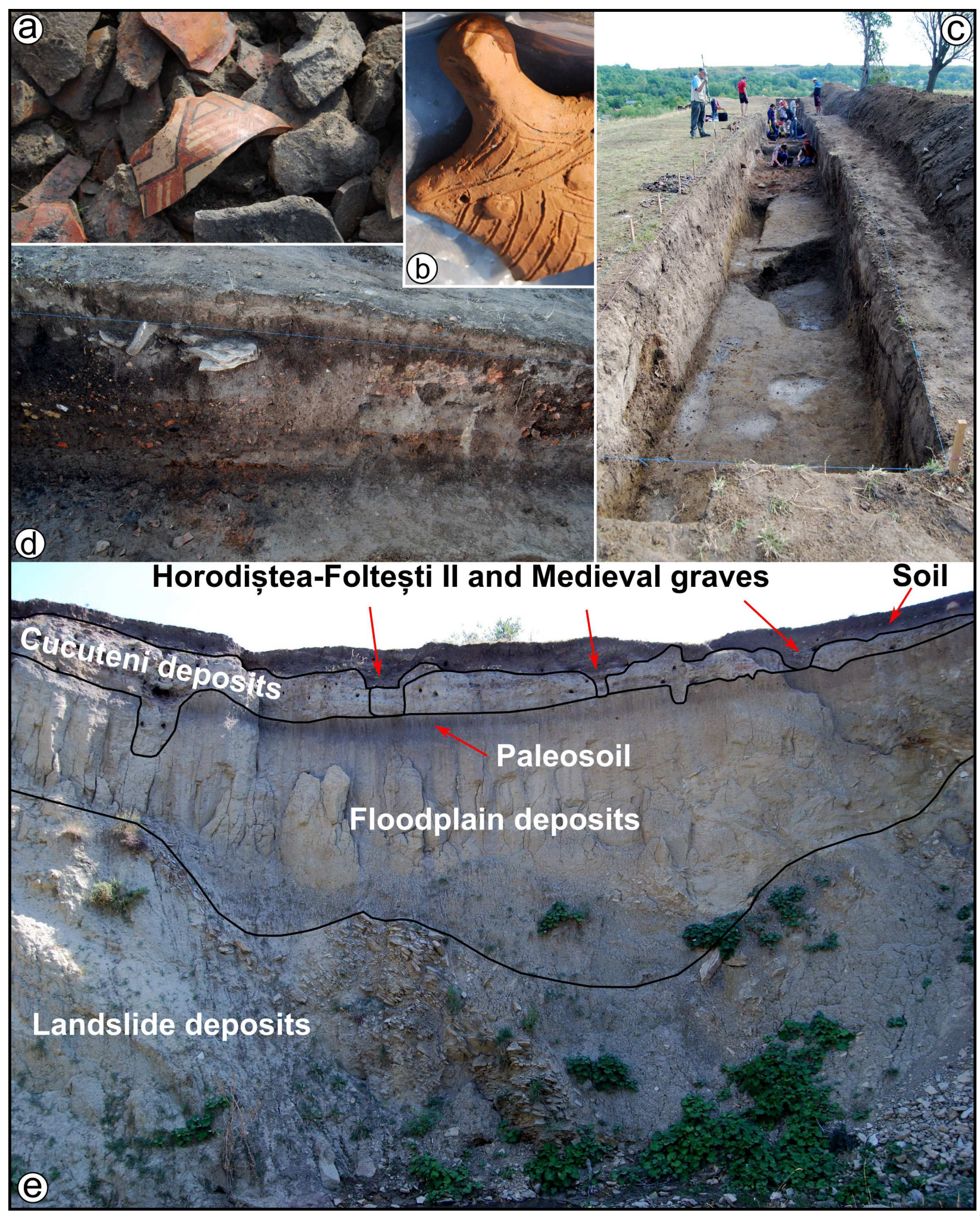

Figure 8 The stratigraphy of the Costești Cier archaeological site: a) ceramics, b) human idol, c) and d) 2016 archaeological trench, e) detail of the archaeological stratigraphy of the western bank. 


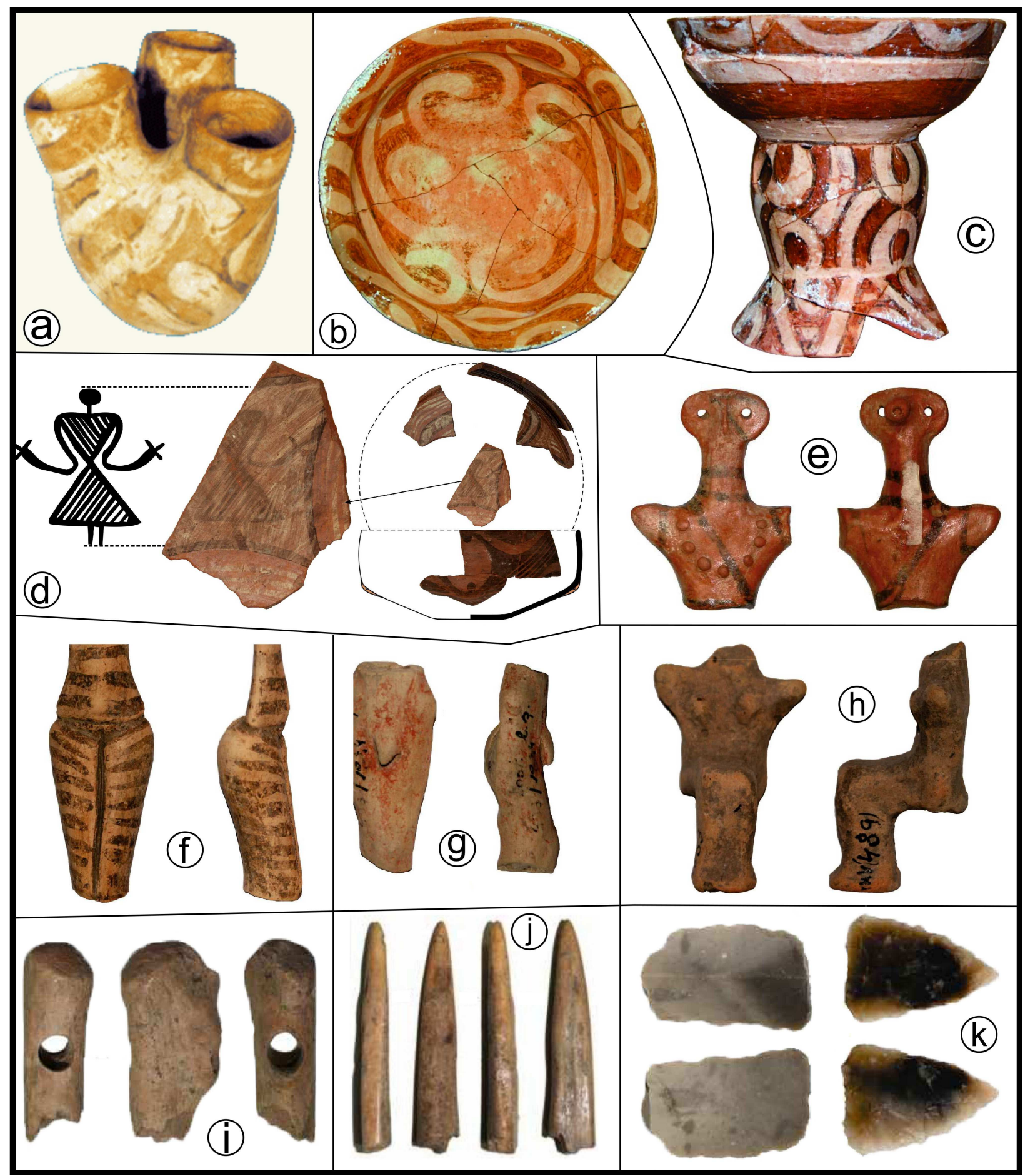

Figure 9 Representative archaeological findings from Costești Cier archaeological site: a) to c) ritual ceramics (Boghian et al., 2014c, 2015; Enea et al., 2016), d) to h) human representations on ceramics or as idols (Boghian et al., 2014c, 2015; Enea et al., 2016), i) and j) bone tools (Boghian et al., 2014c), k) flint tools (Boghian et al., 2014c). 


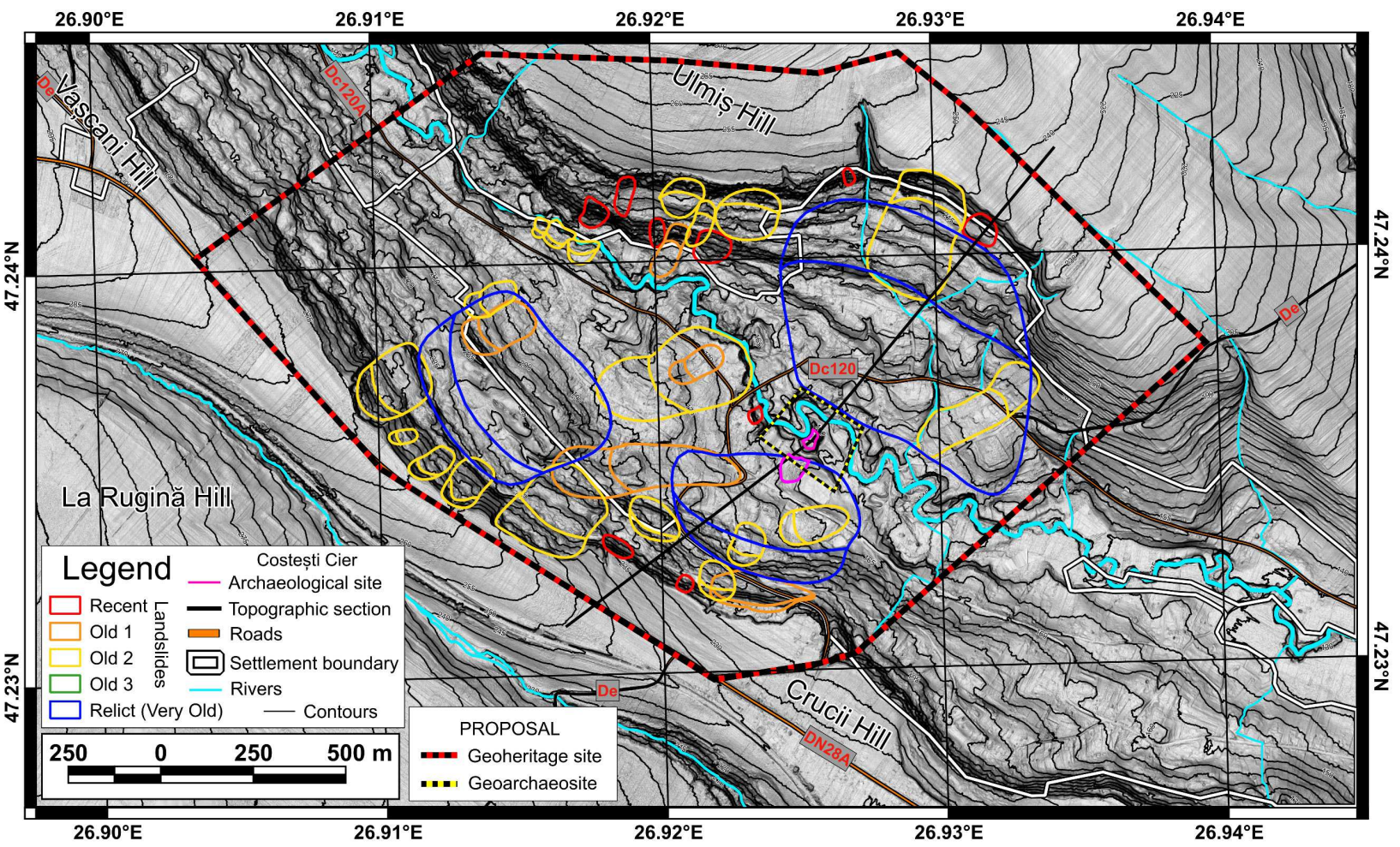

747 Figure 10 The management map of the Bahluieț Valley at Costești geoheritage site.

\begin{tabular}{|c|c|c|}
\hline Level & IUCN & Romanian nomenclature \\
\hline \multirow{5}{*}{ National } & $\mathrm{la}, \mathrm{lb}$ & $\begin{array}{l}\text { natural habitats of flora, fauna, geology, speologic, } \\
\text { paleontologic and pedologic interests }\end{array}$ \\
\hline & II & $\begin{array}{|cc|}\text { natural areas with representative sample of physical geography, flora, } \\
\text { National Park } \\
\text { fauna, ghidrological, geology, speologic, paleontologic and pedologic interests }\end{array}$ \\
\hline & III & 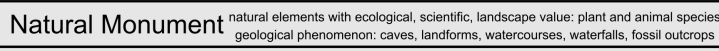 \\
\hline & $\mathrm{Ib}, \mathrm{IV}$ & $\begin{array}{l}\text { Natural Reserve } \begin{array}{c}\text { natural habitats of flora, fauna, geology, speologic, paleontologic } \\
\text { and pedologic interests }\end{array} \\
\end{array}$ \\
\hline & $\mathrm{V}, \mathrm{VI}$ & $\begin{array}{l}\text { Natural Park } \begin{array}{c}\text { natural areas with representative landscapes, including human induced, } \\
\text { which have a great landscape or cultural value and also biodiversity }\end{array} \\
\end{array}$ \\
\hline \multirow{3}{*}{ International } & & Biosphere Reserve \\
\hline & & Wetland of International Importance \\
\hline & & Natural Site for Universal Natural Heritage \\
\hline \multirow{3}{*}{$\begin{array}{l}\text { EU } \\
\text { Natura } 2000\end{array}$} & \multirow{3}{*}{ IV } & Site of community importance \\
\hline & & Special Area for Conservation (for habitats and populations) \\
\hline & & Area for Special Protection fo Birds \\
\hline $\begin{array}{l}\text { UNESCO } \\
\text { Global } \\
\text { Geoparks }\end{array}$ & $\mathrm{V}, \mathrm{VI}$ & Geoparks \\
\hline $\begin{array}{l}\text { County or } \\
\text { local }\end{array}$ & $\mathrm{III}, \mathrm{V}$ & $\begin{array}{l}\text { Sometimes all of the above protected areas are included in this level, and classified } \\
\text { accordingly. The following types are eincluded only in this levell dendrological parks, special } \\
\text { forestry perimeters (anti-ersional plantations), protected trees (which are also declared } \\
\text { natural monments vert often). }\end{array}$ \\
\hline
\end{tabular}

Figure 11 The topographic situation of the geomorpho-archeosite and the bank retreat of the meander island. 


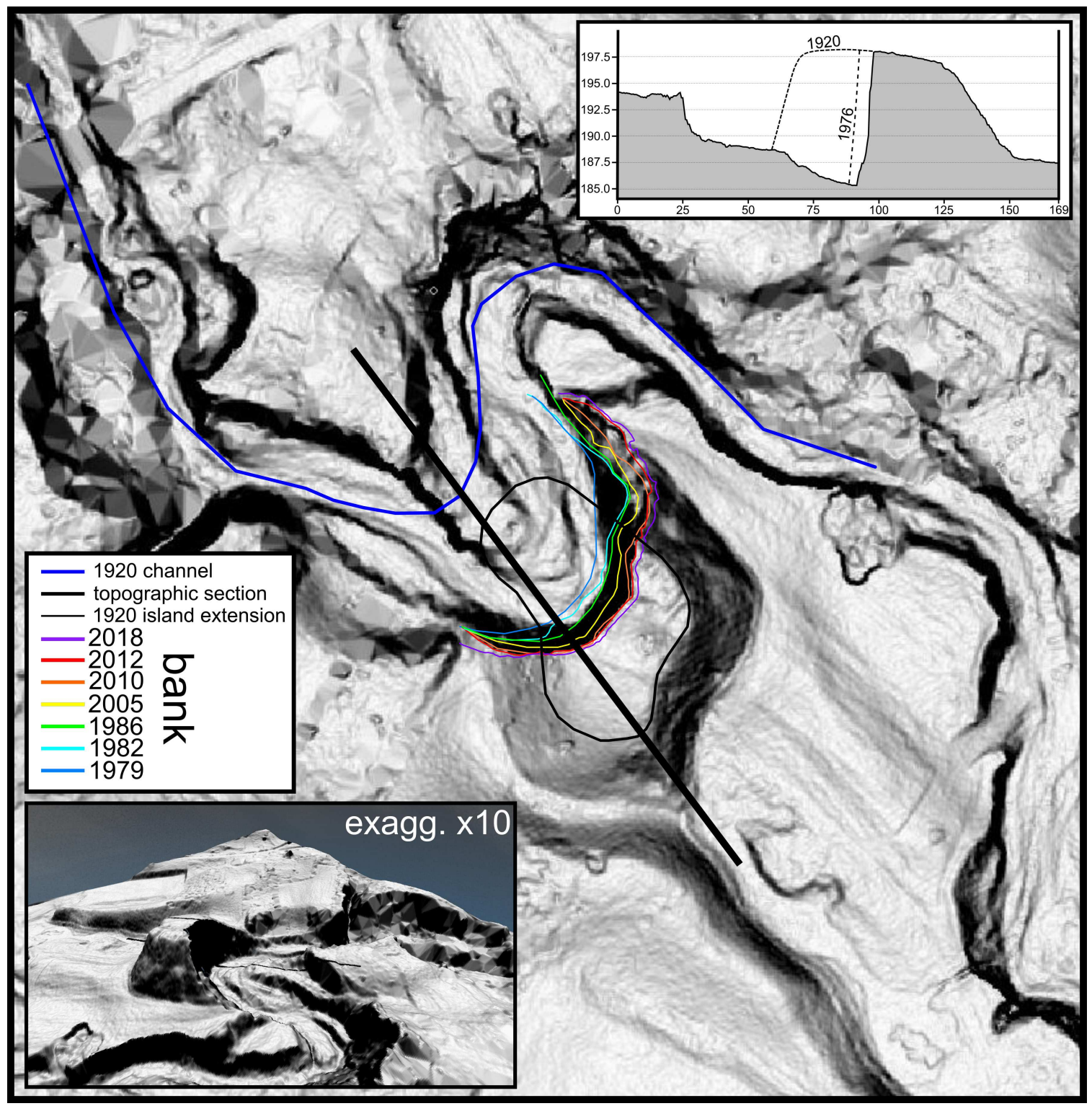

751

Figure 12 Equivalence between the IUCN and Romanian protected areas categories (adapted after Appleton 2010). 


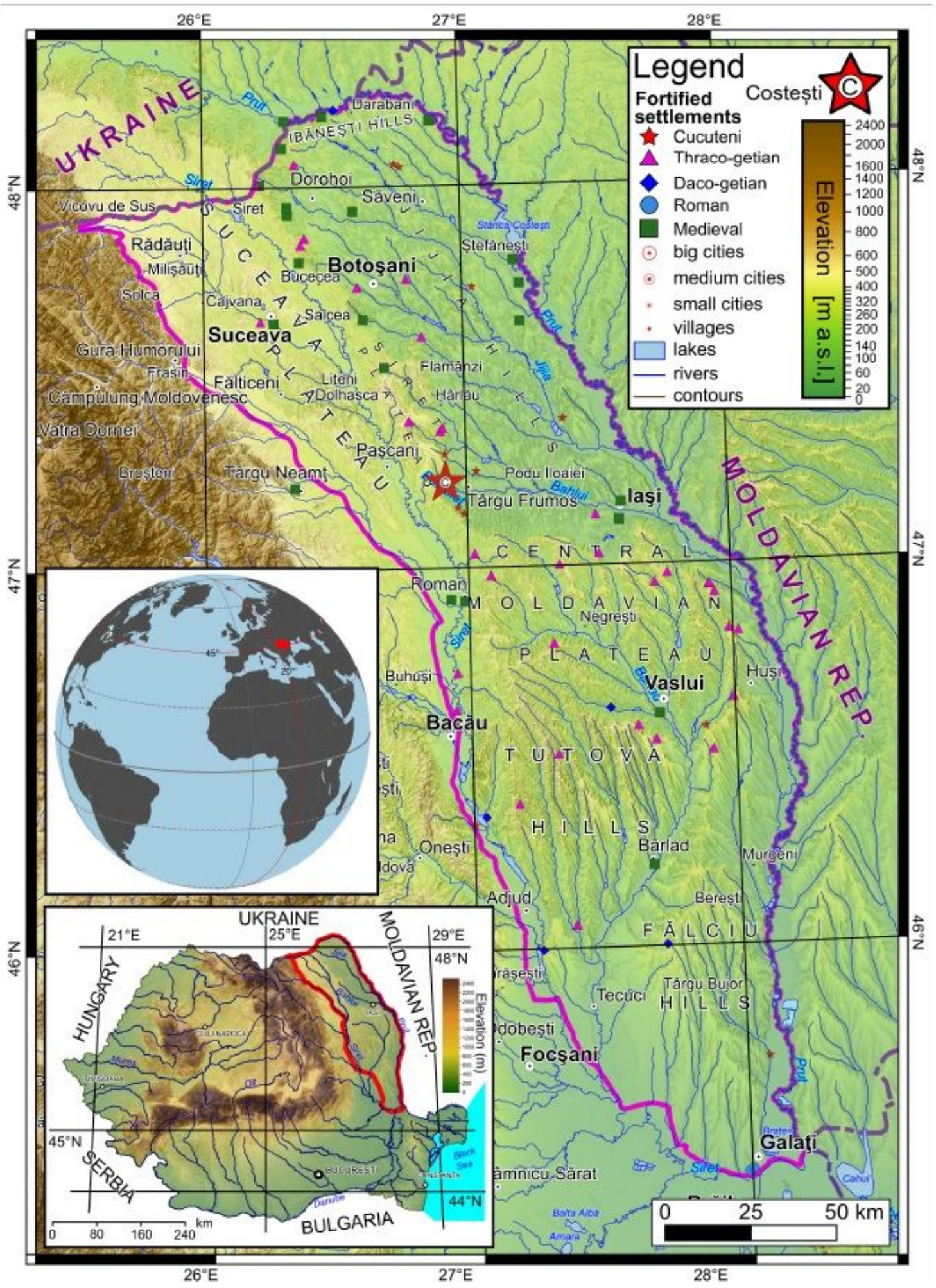

Figure 1

The geographic localization of the studied site within the Eastern Romania and the Moldavian Plateau. 


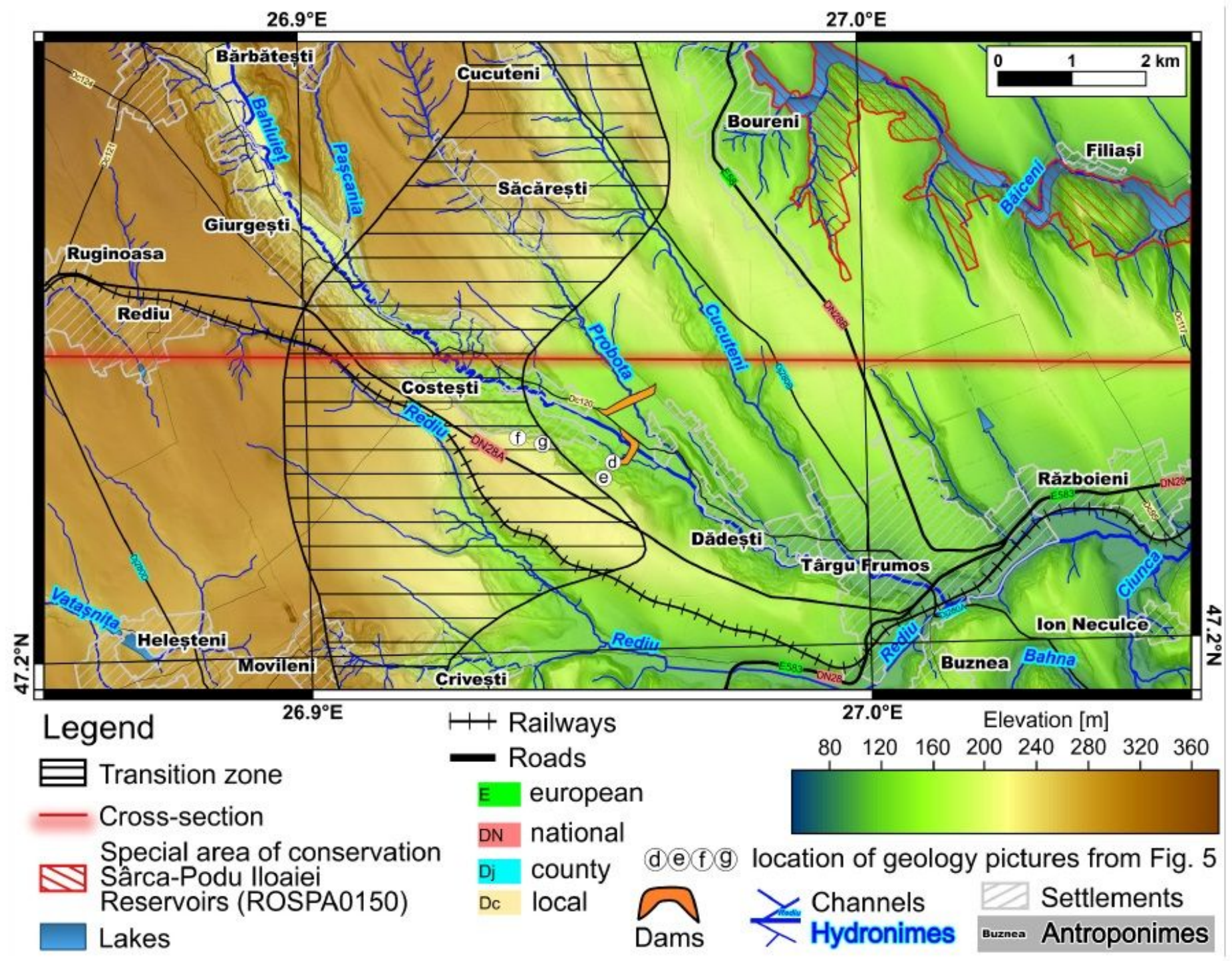

Figure 2

The location of the studied site at the transition zone between Siret Plateau and Jijia Hills. 


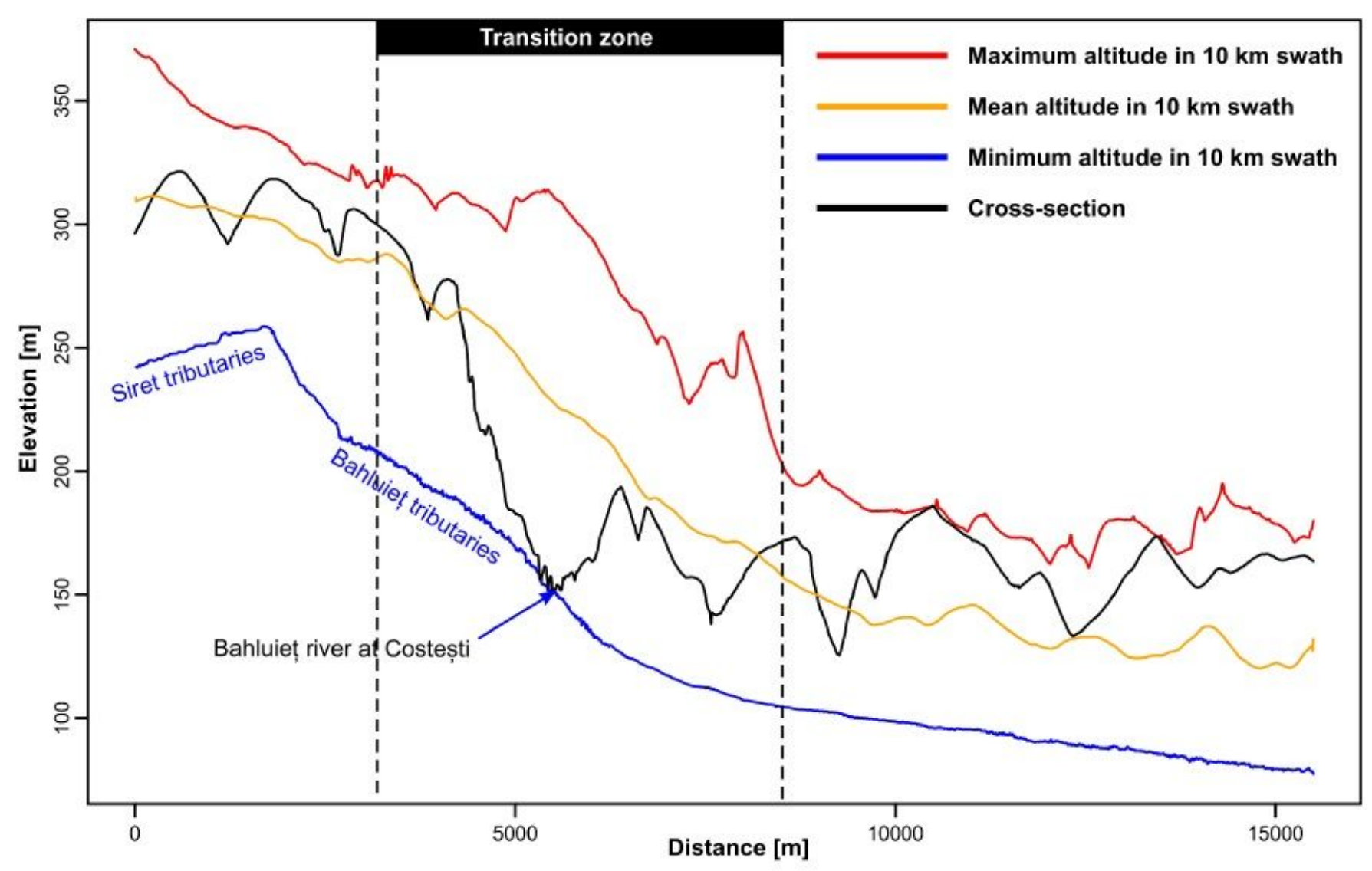

Figure 3

Swath cross-section (10 km wide) through the transition zone between Siret Plateau and Jijia Hills.

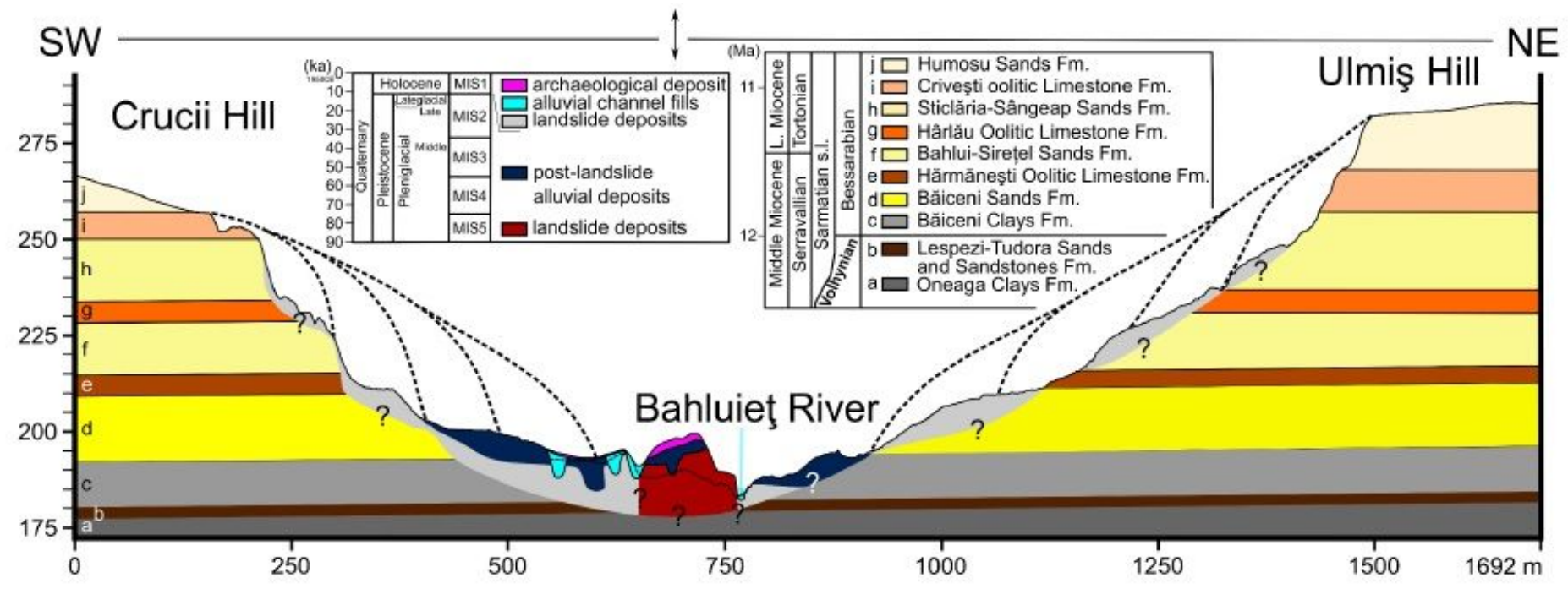

Figure 4

Cross-sectional geomorphological profile through Bahluieț Valley in the Costești - Cier site area interpreted based on geological data from Macarovici and Turculeț (1959), Ștefan (1989), fieldwork and Niculiță et 
al. 2017 ERT data; question marks show interpolated boundaries uncertain levels of lithological correlation; dashed lines indicate possible profiles of the hillslopes between landslide events.

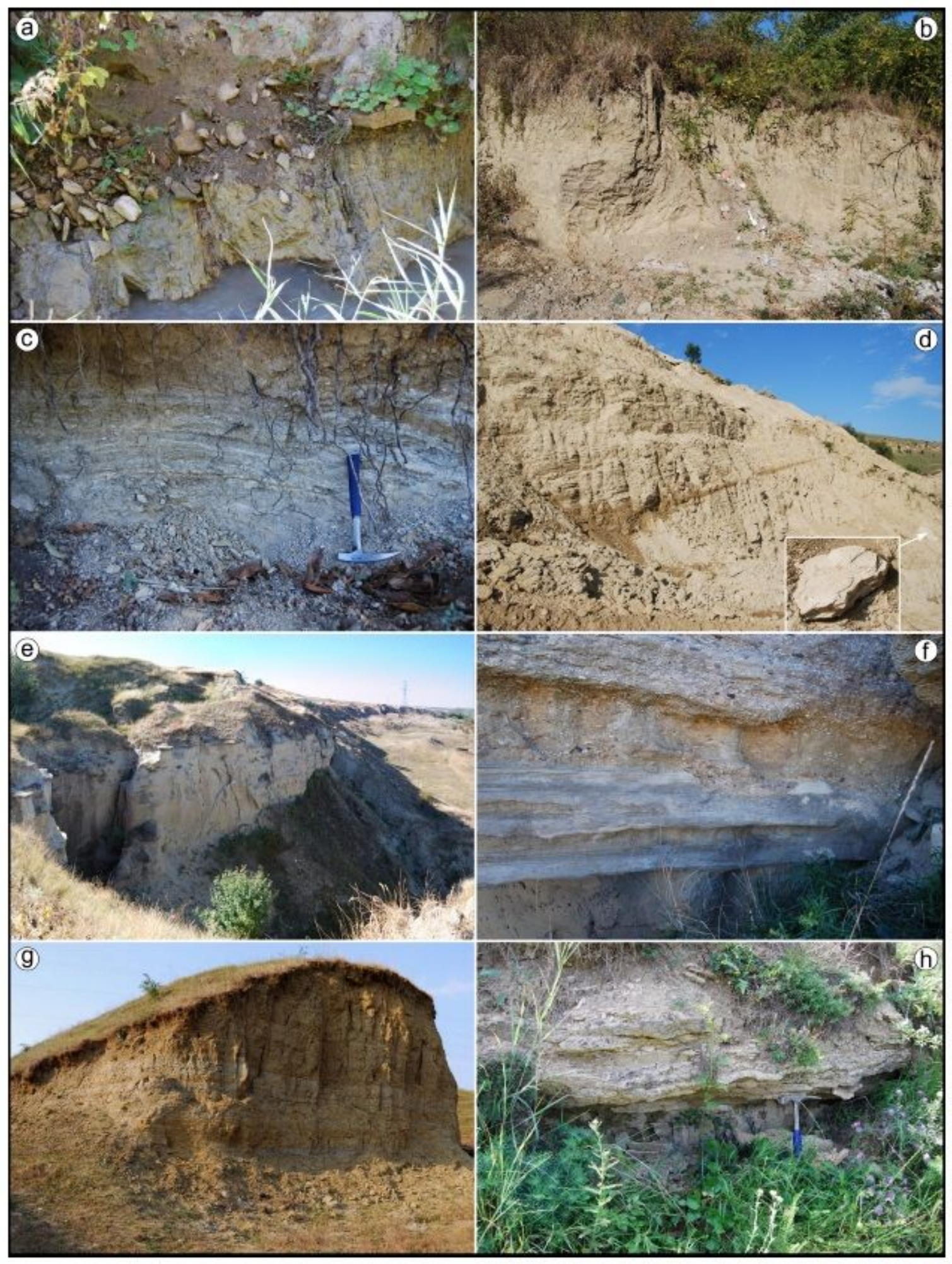

\section{Figure 5}

The geological formation identified in the field: a) overturned Oneaga Clays outcropping in the Bahluieț channel, b) Lespezi-Tudora Sands outcropping in the Bahluieț floodplain, c) Băiceni clays outcropping on the left hillslope in a quarry, d) Băiceni Sands outcropping in a quarry on the right hillslope, the inset 
showing a stone from the overlapping Hărmănești Oolitic Limestone, e) Bahlui Sirețel Sands outcropping in a gully bank on the right hillslope, f) Hârlău Oolitic Limestone outcropping in a landslide scarp on the right hillslope, g) Sticlăria-Sângeap Sands outcropping in a road cut on the right hillslope, h) Crivești Oolitic Limestone outcropping in a gully on the scarp of the Costești landslide.

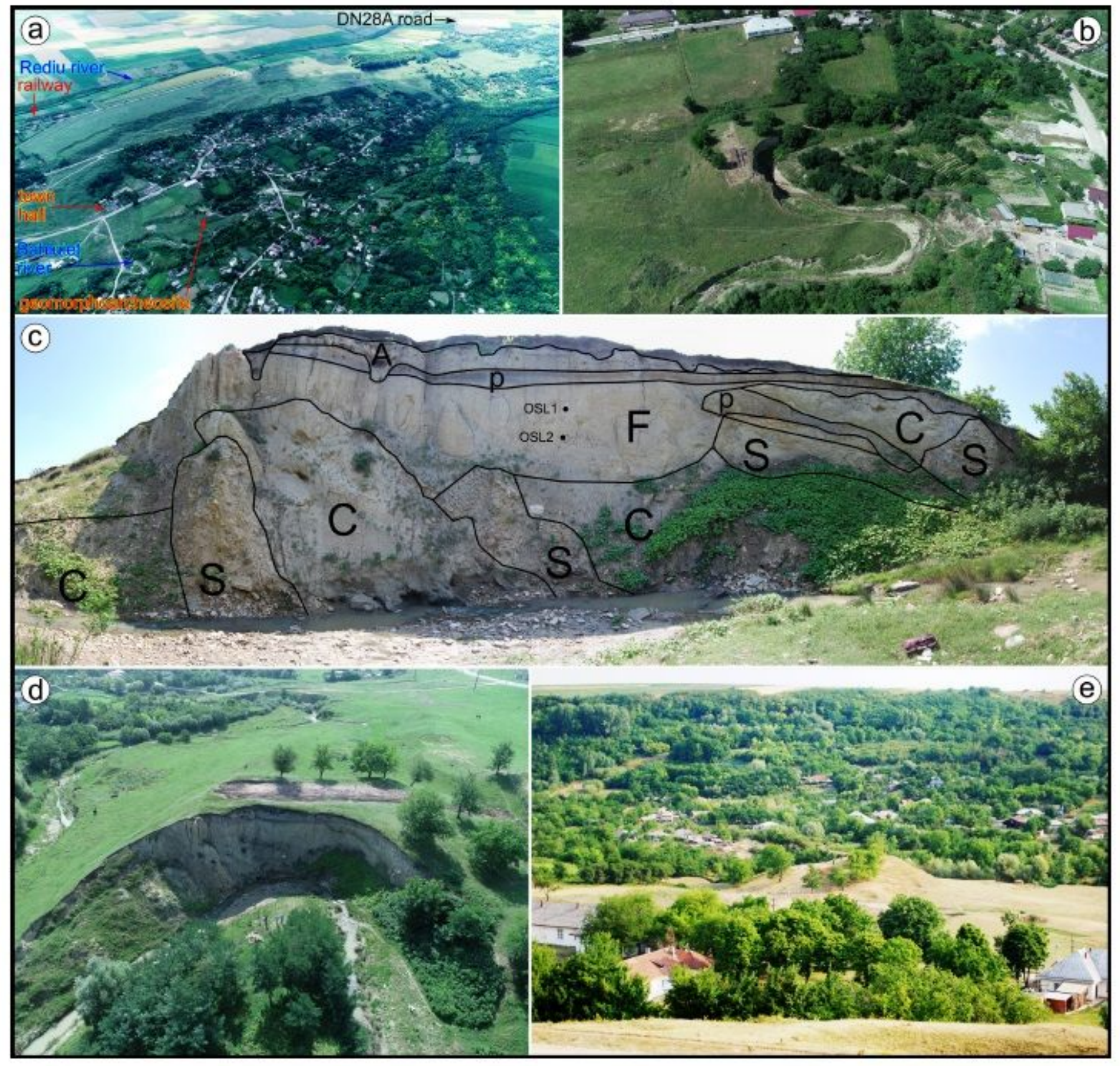

\section{Figure 6}

The environment of the geoheritage site Bahluieț Valley at Costești and of the Costești - Cier archaeological site: a) aerial view of the geoheritage site from the north-east, b) aerial view of the geomorfoarcheosite, $\mathrm{C}$ ) view of the eroded bank with the stratigraphic situation (S - sandstone, C mudstone, F - loamy terrace deposit, p - paleosoil, A - archaeological deposit, OSL1 and 2 - the location 
of OSL samples), d) aerial view of the meander island eroded bank, e) view of the meander island from above the Costești town hall.

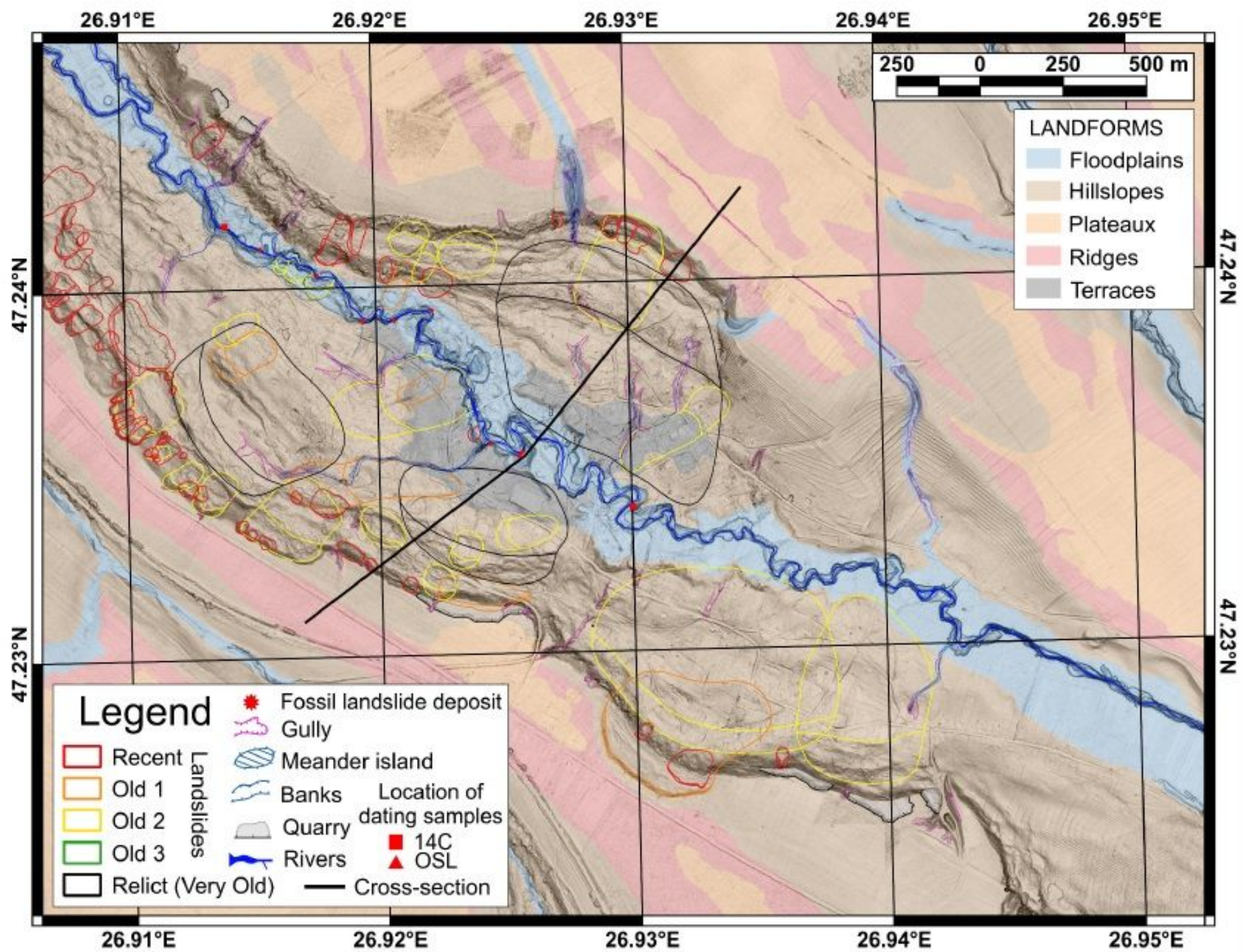

Figure 7

The geomorphological map of Bahluieț Valley at Costești geoheritage site. 


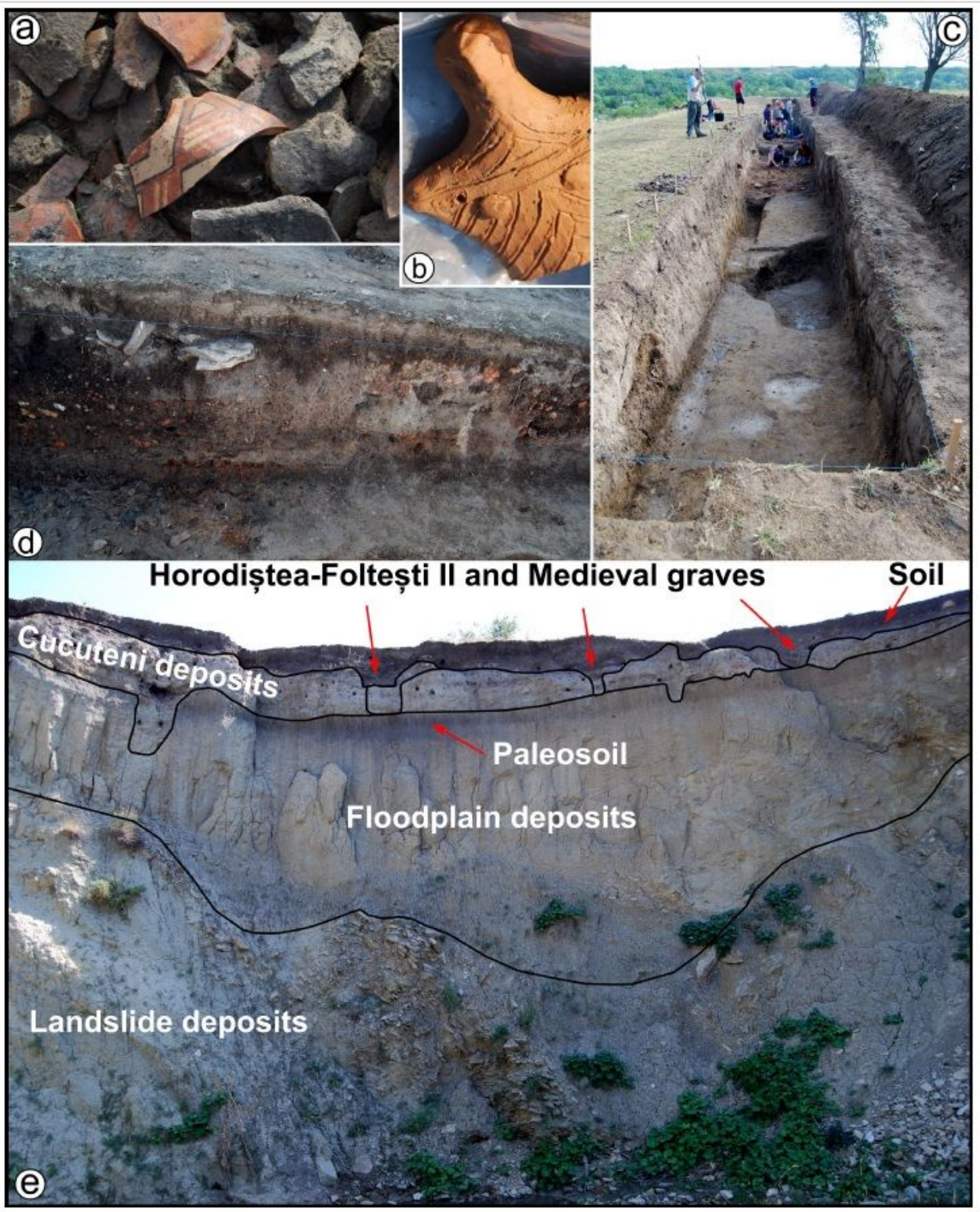

Figure 8

The stratigraphy of the Costești Cier archaeological site: a) ceramics, b) human idol, c) and d) 2016 archaeological trench, e) detail of the archaeological stratigraphy of the western bank. 


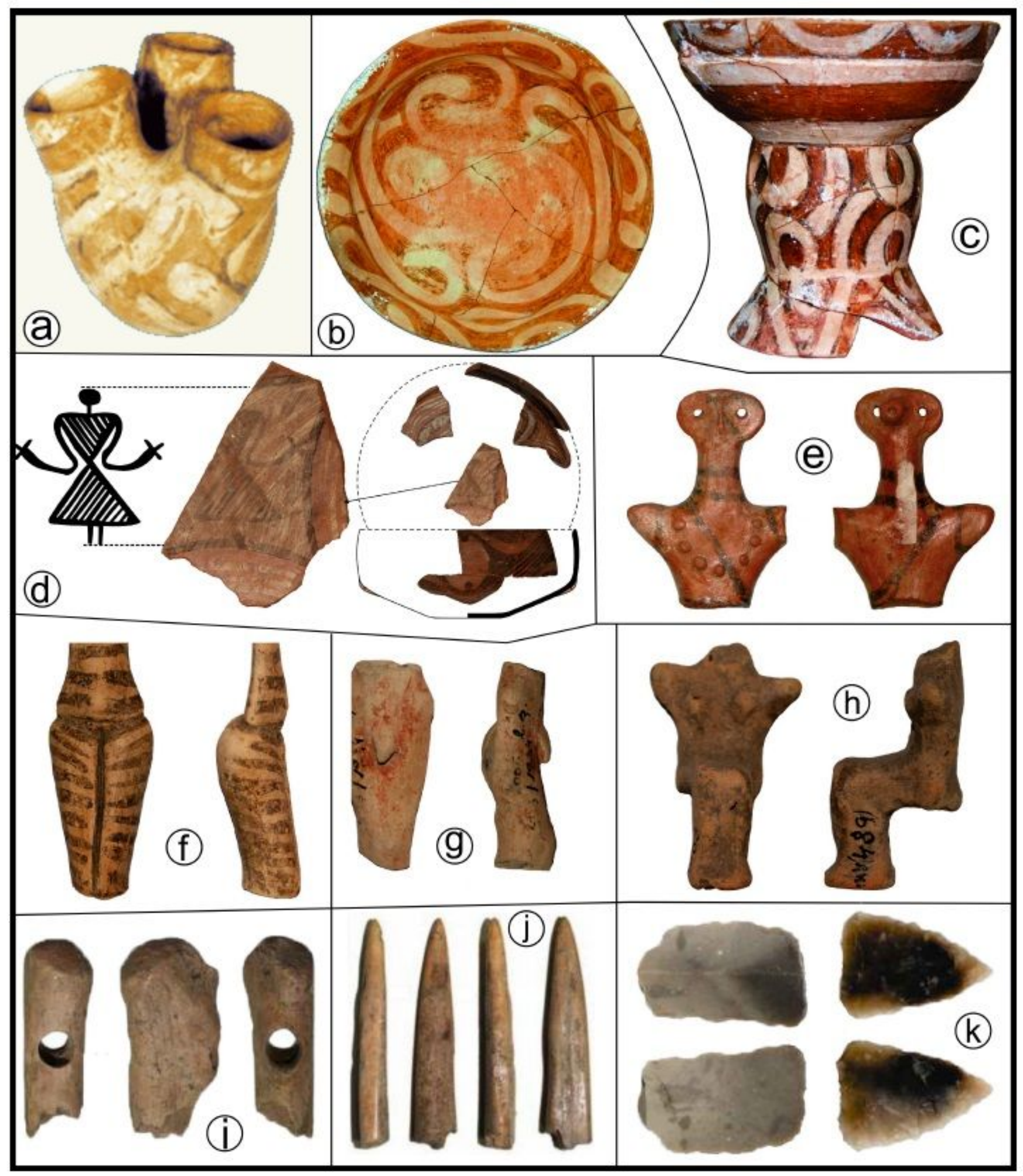

Figure 9

Representative archaeological findings from Costești Cier archaeological site: a) to c) ritual ceramics (Boghian et al., 2014c, 2015; Enea et al., 2016), d) to h) human representations on ceramics or as idols (Boghian et al., 2014c, 2015; Enea et al., 2016), i) and j) bone tools (Boghian et al., 2014c), k) flint tools (Boghian et al., 2014c). 


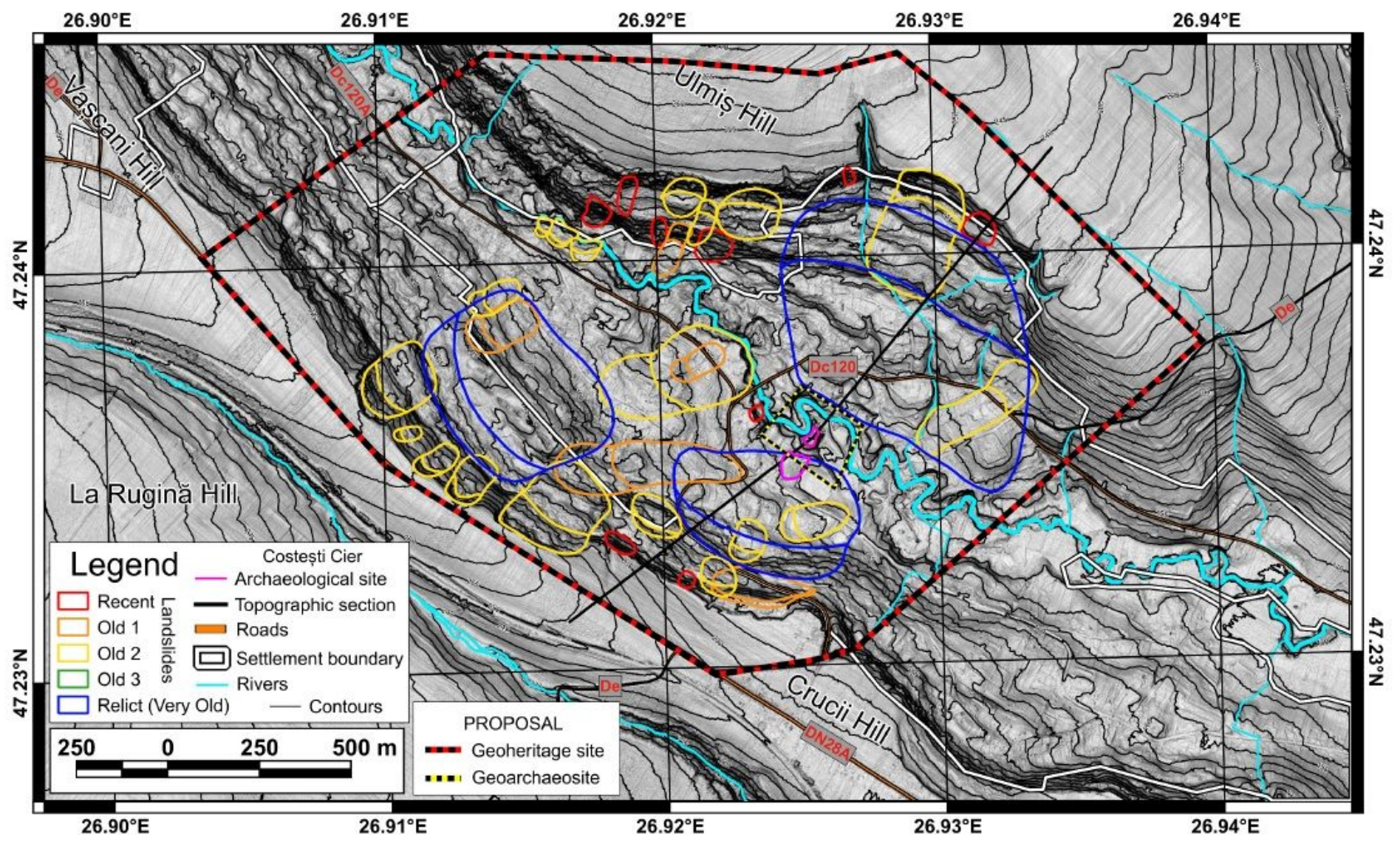

Figure 10

The management map of the Bahluieț Valley at Costești geoheritage site. 


\begin{tabular}{|c|c|c|}
\hline Level & IUCN & Romanian nomenclature \\
\hline \multirow{5}{*}{ National } & la, lb & $\begin{array}{l}\text { natural habitats of flora, fauna, geology, speologic, } \\
\text { paleontologic and pedologic interests }\end{array}$ \\
\hline & II & $\begin{array}{lc}\text { National Park } & \begin{array}{c}\text { natural areas with representative sample of physical geography, flora, } \\
\text { fauna, ghidrological, geology, speologic, paleontologic and pedologic interests }\end{array}\end{array}$ \\
\hline & III & 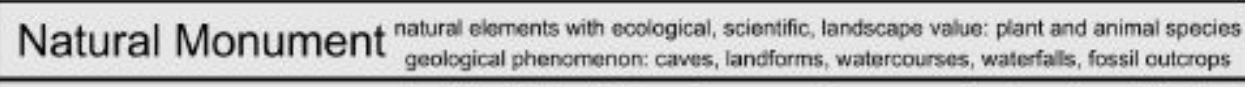 \\
\hline & $\mathrm{Ib}, \mathrm{IV}$ & $\begin{array}{c}\text { Natural Reserve natural habitats of flora, fauna, geology, speologic, paleontologic } \\
\text { and pedologic interests }\end{array}$ \\
\hline & $\mathrm{V}, \mathrm{VI}$ & $\begin{array}{c}\text { Natural Park } \begin{array}{c}\text { natural areas with representative landscapes, including human induced, } \\
\text { which have a great landscape or cultural value and also biodiversity }\end{array} \\
\end{array}$ \\
\hline \multirow{3}{*}{ International } & & Biosphere Reserve \\
\hline & & Wetland of International Importance \\
\hline & & Natural Site for Universal Natural Heritage \\
\hline \multirow{3}{*}{$\begin{array}{c}\text { EU } \\
\text { Natura } 2000\end{array}$} & \multirow{3}{*}{ IV } & Site of community importance \\
\hline & & Special Area for Conservation (for habitats and populations) \\
\hline & & Area for Special Protection fo Birds \\
\hline $\begin{array}{l}\text { UNESCOO } \\
\text { Global } \\
\text { Geoparks }\end{array}$ & $\mathrm{V}, \mathrm{VI}$ & Geoparks \\
\hline $\begin{array}{l}\text { County or } \\
\text { local }\end{array}$ & III,V & $\begin{array}{l}\text { Sometimes all of the above protected areas are included in this level, and classified } \\
\text { accordingly. The following types are includeded only in this level: dendrological parks, special } \\
\text { forestry perimeters (anti-erosional plantations), protected trees (which are also declared } \\
\text { natural monments very often). }\end{array}$ \\
\hline
\end{tabular}

\section{Figure 11}

The topographic situation of the geomorpho-archeosite and the bank retreat of the meander island. 


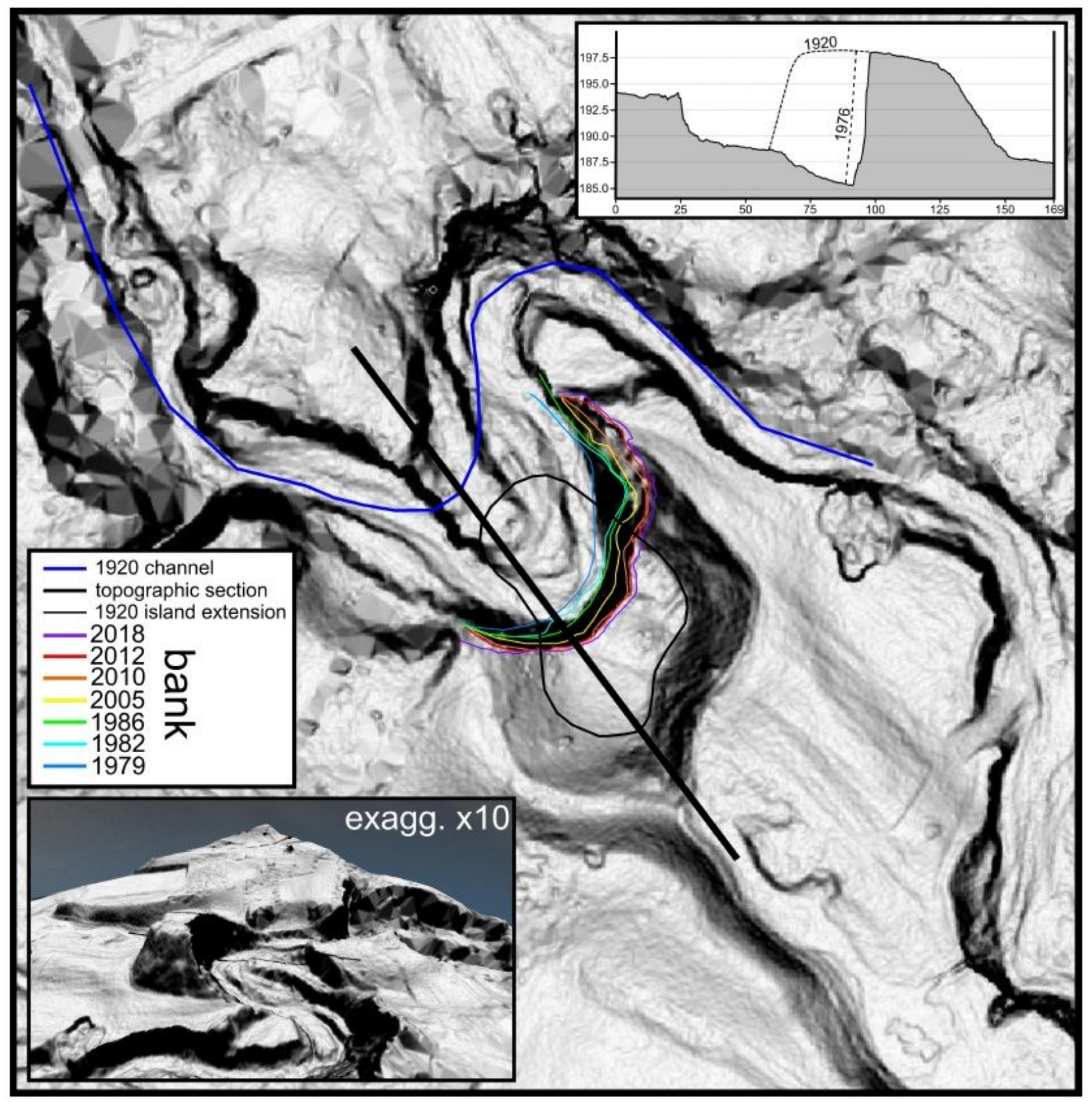

Figure 12

Equivalence between the IUCN and Romanian protected areas categories (adapted after Appleton 2010). 